Prepared in cooperation with the U.S. Environmental Protection Agency as part of the Great Lakes Restoration Initiative

\title{
Water Pressure and Ground Vibrations Induced by Water Guns at a Backwater Pond on the Illinois River near Morris, Illinois
}

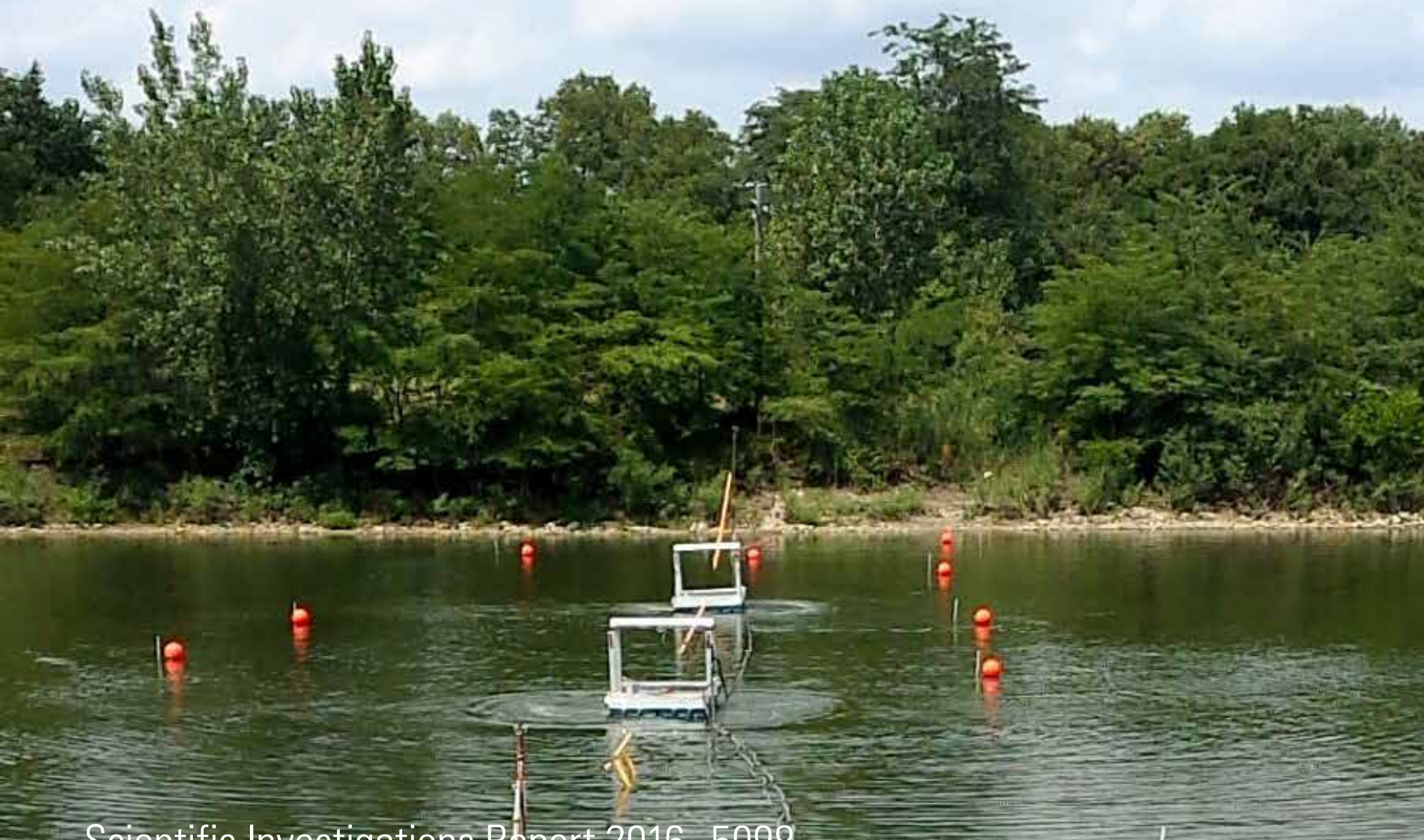

Scientific Investigations 
Cover. Photograph showing the 2014 water gun setup. Back cover, Photograph showing the 2015 water gun setup. Both photographs taken at a backwater pond on the Illinois river near Morris, Illinois. 


\section{Water Pressure and Ground Vibrations Induced by Water Guns at a Backwater Pond on the Illinois River near Morris, Illinois}

By Carolyn M. Koebel and Rachel M. Egly

Prepared in cooperation with the U.S. Environmental Protection Agency as part of the Great Lakes Restoration Initiative

Scientific Investigations Report 2016-5098 


\title{
U.S. Department of the Interior SALLY JEWELL, Secretary
}

\section{U.S. Geological Survey Suzette M. Kimball, Director}

\author{
U.S. Geological Survey, Reston, Virginia: 2016
}

For more information on the USGS - the Federal source for science about the Earth, its natural and living resources, natural hazards, and the environment-visit http://www.usgs.gov or call 1-888-ASK-USGS.

For an overview of USGS information products, including maps, imagery, and publications, visit http://www.usgs.gov/pubprod/.

Any use of trade, firm, or product names is for descriptive purposes only and does not imply endorsement by the U.S. Government.

Although this information product, for the most part, is in the public domain, it also may contain copyrighted materials as noted in the text. Permission to reproduce copyrighted items must be secured from the copyright owner.

Suggested citation:

Koebel, C.M., and Egly, R.M., 2016, Water pressure and ground vibrations induced by water guns at a backwater pond on the Illinois River near Morris, Illinois: U.S. Geological Survey Scientific Investigations Report 2016-5098, 29 p., http://dx.doi.org/10.3133/sir20165098.

ISSN 2328-0328 (online) 


\section{Contents}

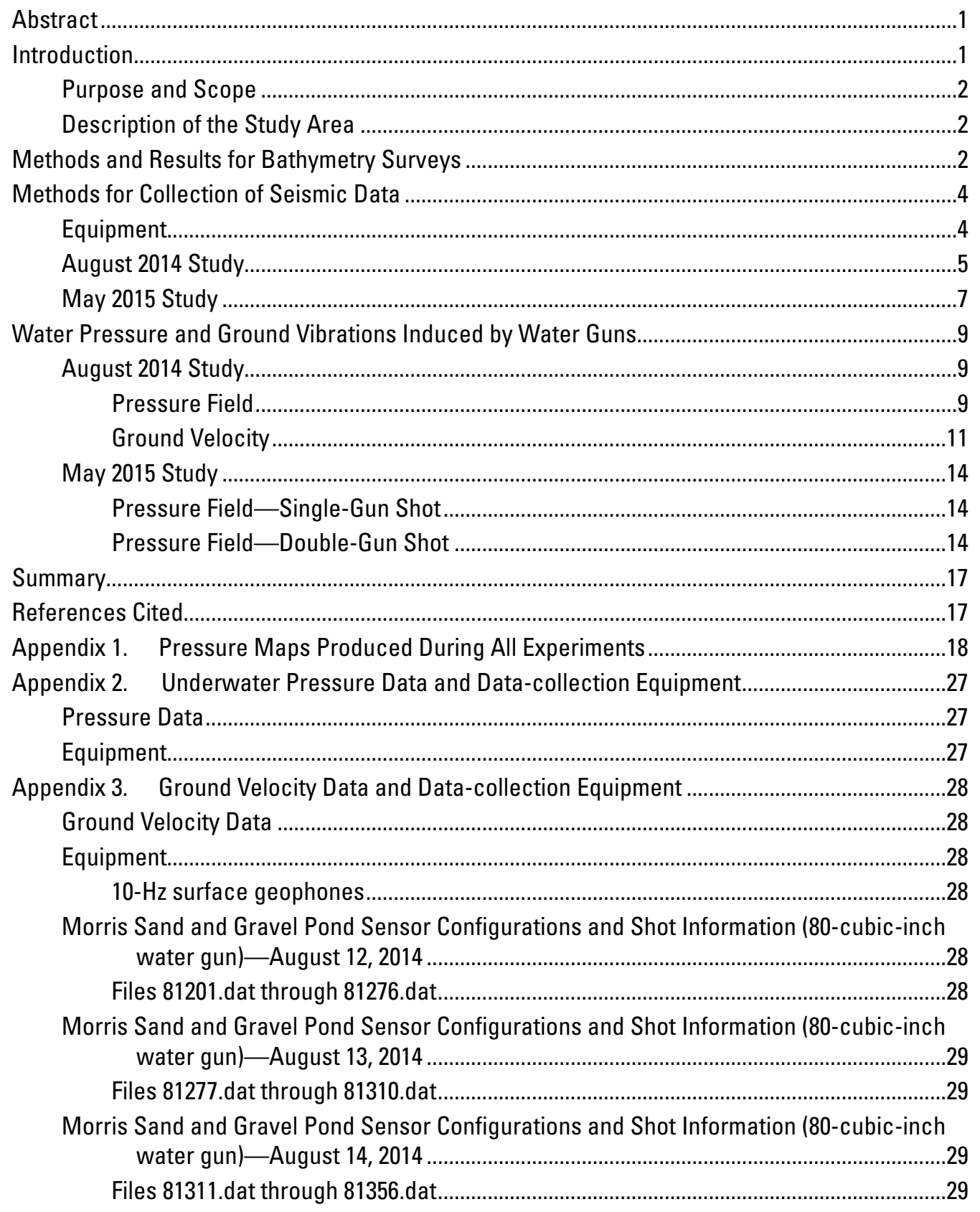




\section{Figures}

1. Schematic diagram of a water gun firing.. . .1

2. Location of the study area in a pond on the Hanson Material Service Corporation property, Morris, Illinois

3. Pit bathymetry data from July 2013 and December 2014, Morris, Illinois ........................................ 3

4. Location of the water guns and netting to create a simulated lock approach channel within the backwater pond in 2014 and 2015

5. Diagram of the equipment setup for the August 2014 study............................................................. 6

6. Diagram of the hydrophone setup for the May 2015 study ........................................................

7. Diagram of the underwater blast sensor setup for the May 2015 study ............................................. 8

8. Comparison of the recorded pressures at various depths between blast sensors and hydrophones.

9. Pressure maps from two 80 -cubic-inch water guns fired at 1,550 pounds per square inch, for measurements recorded by hydrophones located at depths of 1 foot, 2 feet, 5 feet, and 8 feet below the water surface of a backwater pond at Morris, Illinois, August 2014.

10. Plan-view map and cross-sectional pressure maps from two 80-cubic-inch water guns fired at 1,550 pounds per square inch

11. Spatial distribution of the relative standard deviation for each five-shot grouping, measured at depths of 1 foot, 5 feet, and 12 feet below the water surface for experiments in August 2014

12. Geophone component maximum velocity from each shot, recorded during water gun firing at Morris, Illinois, August 2014.

13. Maximum velocities recorded at each geophone, by component, during the August 2014 water gun firing at Morris, Illinois

14. Location map of the underwater blast sensor and hydrophone lines chosen for vertical pressure map profiling, May 2015

15. Cross-sectional pressure maps from a 100 -cubic-inch water gun fired at 2,000 pounds per square inch, for measurements from underwater blast sensor and hydrophone profile lines.

16. Pressure map from a 100 - cubic-inch water gun fired at 2,000 pounds per square inch, for measurements at a depth of 5 feet below the water surface of a backwater pond at Morris, Illinois, May 2015.

17. Cross-sectional pressure maps from two 100 -cubic-inch water guns fired at 2,000 pounds per square inch, for measurements from underwater blast sensor and hydrophone lines closest to the water guns, May 2015.

18. Pressure map from two 100-cubic-inch water guns fired at 2,000 pounds per square inch, for measurements at a depth of 5 feet below the water surface of a backwater pond at Morris, Illinois, May 2015.

1-1. Pressure maps from two 80-cubic-inch water guns fired at 1,550 pounds per square inch, for measurements at depths of 1 foot, 2 feet, 3 feet, and 4 feet below the water surface of a backwater pond at Morris, Illinois, August 2014

1-2. Pressure maps from two 80 -cubic-inch water guns fired at 1,550 pounds per square inch, for measurements at depths of $5 \mathrm{feet}, 6 \mathrm{feet}, 7 \mathrm{feet}$, and 8 feet below the water surface of a backwater pond at Morris, Illinois, August 2014

1-3. Pressure maps from two 80 -cubic-inch water guns fired at 1,550 pounds per square inch, for measurements at depths of 9 feet, 10 feet, 11 feet, and 12 feet below the water surface of a backwater pond at Morris, Illinois, August 2014 
1-4. Plan-view map and cross-sectional pressure maps from two 80-cubic-inch water guns fired at 1,550 pounds per square inch

1-5. Pressure maps from a 100 -cubic-inch water gun fired at 2,000 pounds per square inch, for measurements at depths of 1 foot, 3 feet, 5 feet, 7 feet, 9 feet, and 11 feet below the water surface of a backwater pond at Morris, Illinois, May 2015

1-6. Pressure maps from two 100-cubic-inch water guns fired at 2,000 pounds per square inch, for measurements at depths of 1 foot, 3 feet, 5 feet, 7 feet, 9 feet, and 11 feet below the water surface of a backwater pond at Morris, Illinois, May 2015

1-7. Cross-sectional pressure maps from a 100-cubic-inch water gun fired at 2,000 pounds per square inch, for measurements from underwater blast sensor and hydrophone profile lines.

1-8. Cross-sectional pressure maps from two 100-cubic-inch water guns fired at 2,000 pounds per square inch, for measurements from underwater blast sensor and hydrophone profile lines closest to the water guns.

\section{Conversion Factors}

U.S. customary units to International System of Units

\begin{tabular}{|c|c|c|}
\hline Multiply & By & To obtain \\
\hline \multicolumn{3}{|c|}{ Length } \\
\hline inch (in.) & 2.54 & centimeter $(\mathrm{cm})$ \\
\hline inch (in.) & 25.4 & millimeter $(\mathrm{mm})$ \\
\hline foot $(\mathrm{ft})$ & 0.3048 & meter $(\mathrm{m})$ \\
\hline mile (mi) & 1.609 & kilometer $(\mathrm{km})$ \\
\hline \multicolumn{3}{|c|}{ Area } \\
\hline square inch $\left(\right.$ in $\left.^{2}\right)$ & 6.452 & square centimeter $\left(\mathrm{cm}^{2}\right)$ \\
\hline \multicolumn{3}{|c|}{ Volume } \\
\hline cubic inch $\left(\mathrm{in}^{3}\right)$ & 16.39 & cubic centimeter $\left(\mathrm{cm}^{3}\right)$ \\
\hline cubic inch $\left(\mathrm{in}^{3}\right)$ & 0.01639 & cubic decimeter $\left(\mathrm{dm}^{3}\right)$ \\
\hline cubic inch $\left(\mathrm{in}^{3}\right)$ & 0.01639 & liter $(\mathrm{L})$ \\
\hline \multicolumn{3}{|c|}{ Velocity } \\
\hline inch per second (in/s) & 25.4 & millimeter per second $(\mathrm{mm} / \mathrm{s})$ \\
\hline \multicolumn{3}{|c|}{ Pressure } \\
\hline pound per square inch $\left(\mathrm{lb} / \mathrm{in}^{2}\right)$ & 6.895 & kilopascal $(\mathrm{kPa})$ \\
\hline
\end{tabular}

International System of Units to U.S. customary units

\begin{tabular}{llll}
\hline & Multiply & By & To obtain \\
\hline Length & & \\
\hline $\operatorname{meter}(\mathrm{m})$ & 3.281 & foot $(\mathrm{ft})$ & \\
$\operatorname{meter}(\mathrm{m})$ & 1.094 & yard $(\mathrm{yd})$ & \\
\hline
\end{tabular}

\section{Datum}

Horizontal coordinate information is referenced to the North American Datum of 1983 (NAD 83). 



\title{
Water Pressure and Ground Vibrations Induced by Water Guns at a Backwater Pond on the Illinois River near Morris, Illinois
}

\author{
By Carolyn M. Koebel and Rachel M. Egly
}

\section{Abstract}

Three different geophysical sensor types were used to characterize the underwater pressure waves and ground velocities generated by the underwater firing of seismic water guns. These studies evaluated the use of water guns as a tool to alter the movement of Asian carp. Asian carp are aquatic invasive species that threaten to move into the Great Lakes Basin from the Mississippi River Basin. Previous studies have identified a threshold of approximately 5 pounds per square inch $\left(\mathrm{lb} / \mathrm{in}^{2}\right)$ for behavioral modification and for structural limitation of a water gun barrier.

Two studies were completed during August 2014 and May 2015 in a backwater pond connected to the Illinois River at a sand and gravel quarry near Morris, Illinois. The August 2014 study evaluated the performance of two 80 -cubic-inch $\left(\mathrm{in}^{3}\right)$ water guns. Data from the 80 -in ${ }^{3}$ water guns showed that the pressure field had the highest pressures and greatest extent of the $5-\mathrm{lb} / \mathrm{in}^{2}$ target value at a depth of 5 feet (ft). The maximum recorded pressure was $13.7 \mathrm{lb} / \mathrm{in}^{2}$, approximately $25 \mathrm{ft}$ from the guns. The produced pressure field took the shape of a north-south-oriented elongated sphere with the $5-1 \mathrm{~b} / \mathrm{in}^{2}$ target value extending across the entire study area at a depth of $5 \mathrm{ft}$. Ground velocities were consistent over time, at 0.0067 inches per second (in/s) in the transverse direction, $0.031 \mathrm{in} / \mathrm{s}$ in the longitudinal direction, and $0.013 \mathrm{in} / \mathrm{s}$ in the vertical direction.

The May 2015 study evaluated the performance of one and two $100-\mathrm{in}^{3}$ water guns. Data from the $100-\mathrm{in}^{3}$ water guns, fired both individually and simultaneously, showed that the pressure field had the highest pressures and greatest extent of the $5-1 \mathrm{~b} / \mathrm{in}^{2}$ target value at a depth of $5 \mathrm{ft}$. The maximum pressure was $57.4 \mathrm{lb} / \mathrm{in}^{2}$, recorded at the underwater blast sensor closest to the water guns (at a horizontal distance of approximately $3 \mathrm{ft}$ ), as two guns fired simultaneously. Pressures and extent of the $5-\mathrm{lb}_{\mathrm{in}}{ }^{2}$ target value decrease above and below this 5 -ft depth, producing a relatively north-south-oriented pressure field shaped like an elongated sphere.

\section{Introduction}

Asian carp, primarily bighead carp (Hypophthalmichthys nobilis) and silver carp (Hypophthalmichthys molitrix), are aquatic invasive species that threaten to migrate into the Great Lakes Basin from the Mississippi River Basin, through the Chicago Area Waterway System (CAWS). The U.S. Geological Survey (USGS) is studying the potential effectiveness of using water guns to produce a pressure barrier to direct the movement of Asian carp and reduce the risk of interbasin transfer.

Water guns use high-pressure air to rapidly eject a rated volume of water (fig. 1). The ejection creates a vacuum, which is rapidly filled by water as it collapses back into the empty space. This collapse of water back into empty space produces a pressure wave.

Several studies have investigated the effects of water guns on fish and other marine life. A variety of fish species reportedly displayed a startle-like response by quickly changing direction and velocity when exposed to an underwater pressure wave from a water gun (Boeger and

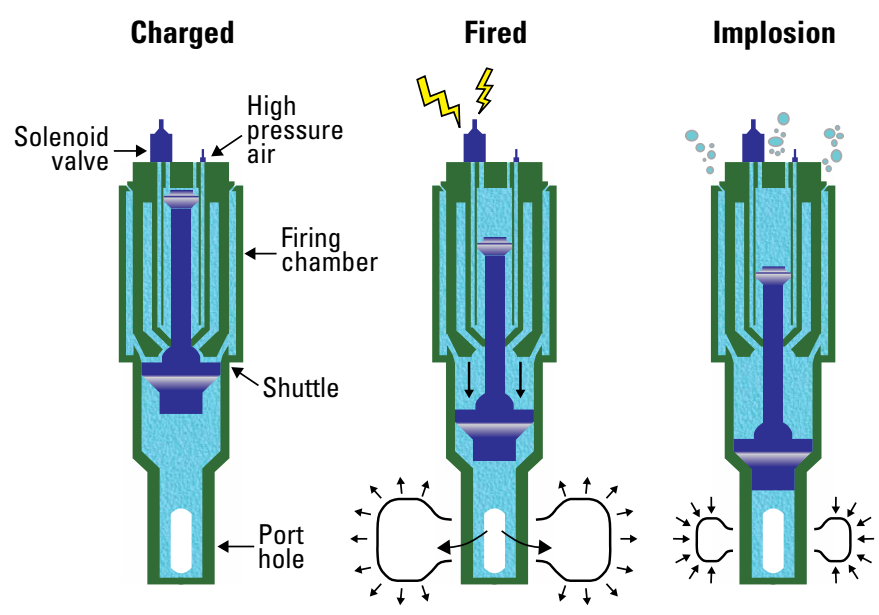

Figure 1. Schematic diagram of a water gun firing. Modified from Layhee and others (2013). 
others, 2006; Gordon and others, 2003; Hirst and Rodhouse, 2000). Other studies report results that range from minimal changes in behavior (Turnpenny and Nedwell, 1994; Wardle and others, 2001) to mortality (Gross and others, 2013).

Fish behavior data, collected as a separate investigation during prior pond experiments (Adams and Morrow, 2015), indicated that a pressure near 4 pounds per square inch $\left(\mathrm{lb} / \mathrm{in}^{2}\right)$ was sufficient to modify the free-swimming movement of Asian carp (Romine and others, 2015). A limitation value for pressures exerted on structures was set at $5 \mathrm{lb} / \mathrm{in}^{2}$, so a target value of $5 \mathrm{lb} / \mathrm{in}^{2}$ was used as a benchmark for the evaluation of water gun barriers in this study.

\section{Purpose and Scope}

The purpose of this report is to present measurements of the physical magnitude and extent of the pressure field in the water and the velocity magnitude on land caused by the firing of water guns; these data were collected during two separate studies, conducted in August 2014 and May 2015, in a backwater pond near Morris, Illinois. Studying the magnitude, direction, and impacts of the pressure output on Asian carp, native species, structures, and other recipients is a larger USGS goal that is not covered in this report. A fish behavior study was conducted concurrently (A.R. Cupp, U.S. Geological Survey, written commun., 2015).

Pressure measurements within the water column were collected using hydrophones and underwater blast sensors (UBS). Velocity measurements on land also were collected using geophones for transverse, longitudinal, and vertical wave propagation.
Data collection near Morris, Illinois consisted of recording pressure values at depth, as well as horizontally, but also determining maximum velocities at and away from the edge of the water with consistent gun location and continuous firing. Pressure maps produced from these two studies may provide a basis for studying the size and shape of the pressure field that can be created under these conditions.

\section{Description of the Study Area}

The study area is a backwater pond connected to the Illinois River on the Hanson Material Service Corporation sand and gravel mining operation property near Morris, Illinois (fig. 2). The pond is about 3 miles (mi) long in the east-west direction, from the western shore to the culvert, and about $0.45 \mathrm{mi}$ at its widest, in the north-south direction. At the study site, the width of the pond is about 300 feet (ft).

\section{Methods and Results for Bathymetry Surveys}

Bathymetry data of the study area were collected with a 1,200 megahertz (MHz) Rio Grande acoustic Doppler current profiler in July 2013 and December 2014 (fig. 3). Data were recorded as depths below the water surface (bws) and were not referenced to a known water-surface elevation. These data were contoured by using Esri ArcMAP (ver. 10.3, http://www.esri. com). A kernel smoothing with barriers algorithm was used to

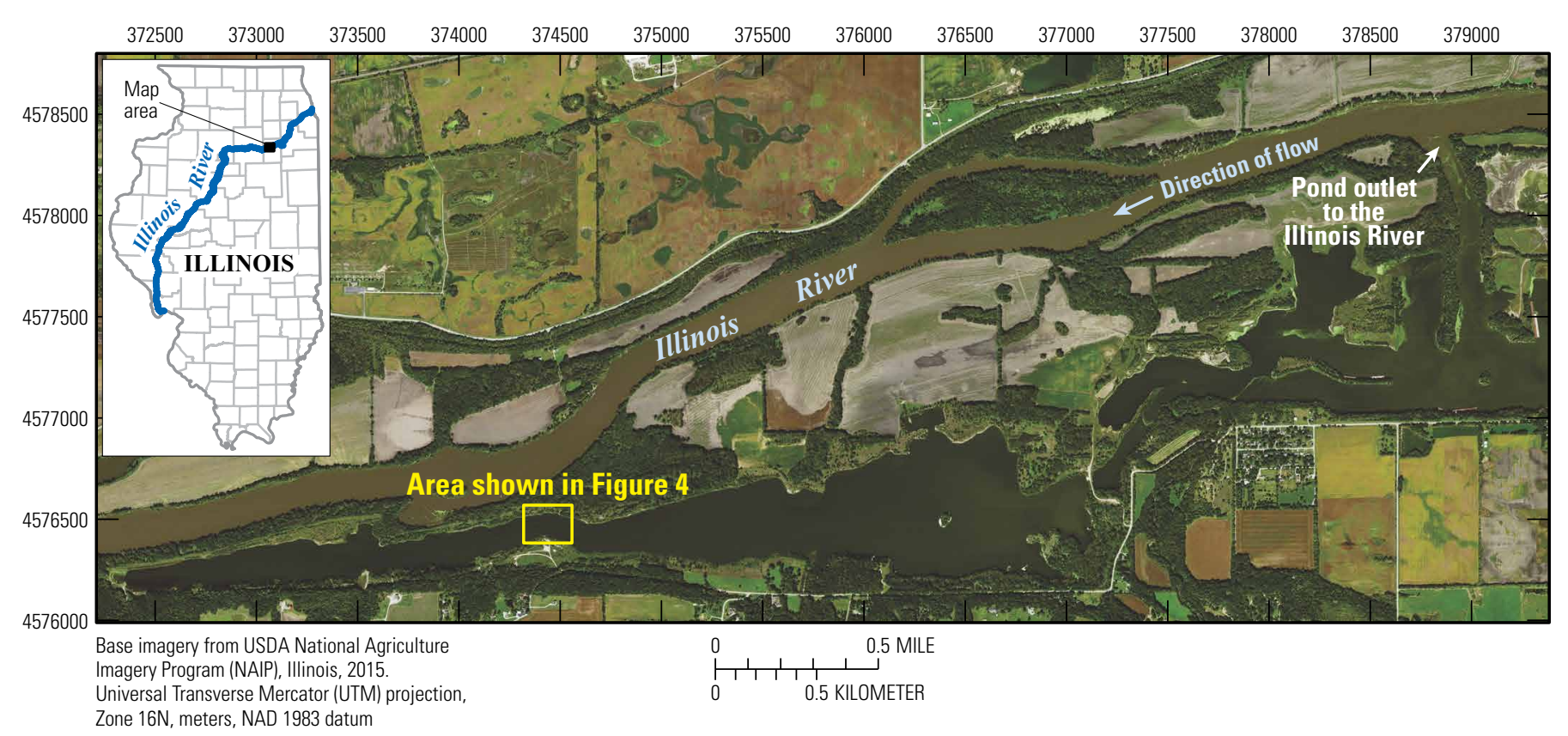

Figure 2. Location of the study area in a pond on the Hanson Material Service Corporation property, Morris, Illinois. 
smooth the data and create bathymetry maps. The July 2013 survey covered the entire west pit. The resulting bathymetry showed water depths ranging from 11 to $13 \mathrm{ft}$ (fig. $3 A$ ). The December 2014 survey covered a quarter mile east and west of the study area. The resulting bathymetry showed water depths ranging from 5 to $10 \mathrm{ft}$ (fig. 3B). The 2013-2014 bathymetry data were used to guide the 2014 and 2015 survey design by determining how deep the hydrophones could be set.
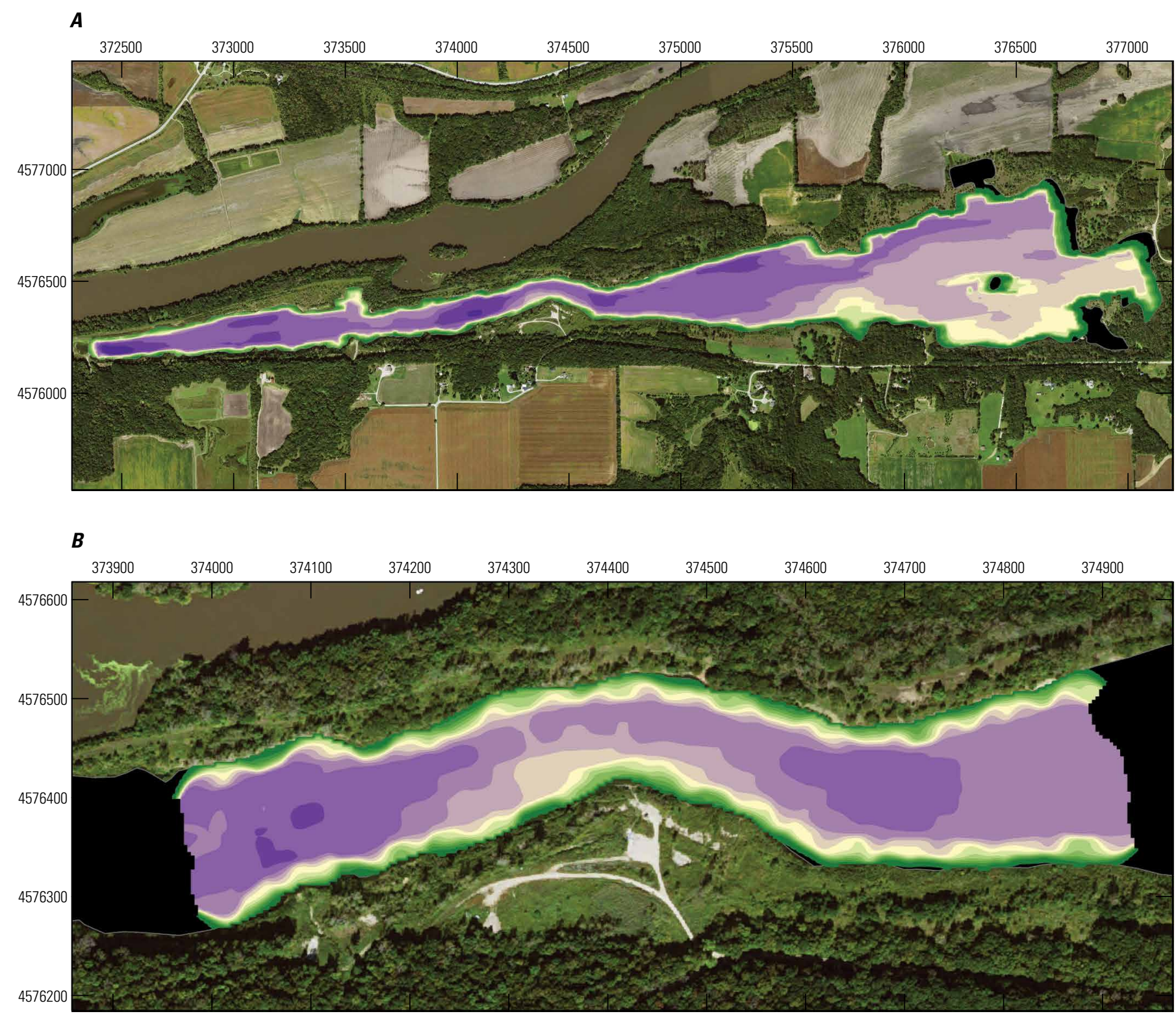

Base imagery from U.S. Department of Agriculture National Agriculture Imagery Program (NAIP), Illinois, 2015 Universal Transverse Mercator (UTM) projection, Zone 16N, meters, NAD 1983 datum.

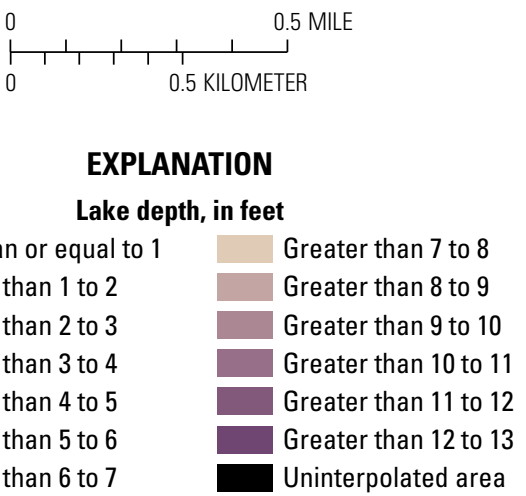

Figure 3. West pit bathymetry data from July $2013(A)$ and December $2014(B)$, Morris, Illinois. 


\section{Methods for Collection of Seismic Data Equipment}

Seismic data were acquired at a backwater pond near Morris, Illinois, from August 12 to 14, 2014, and from May 26 to 29, 2015. Data collection consisted of two separate studies using hydrophones and UBS with the goal of measuring the magnitude and extent of the pressure field produced by firing two water guns. Land velocity data were also collected in 2014 to supplement the pressure data.

Two 80-cubic inch $\left(\mathrm{in}^{3}\right)$ water guns were deployed in the 2014 study and two $100-$ in $^{3}$ water guns were deployed in the 2015 study. The water guns were set approximately $1.3 \mathrm{mi}$ east from the western edge of the pond and secured in a northsouth line (fig. 4). The water guns were bordered by netting so that the only east-west passageway for fish was between the water guns.

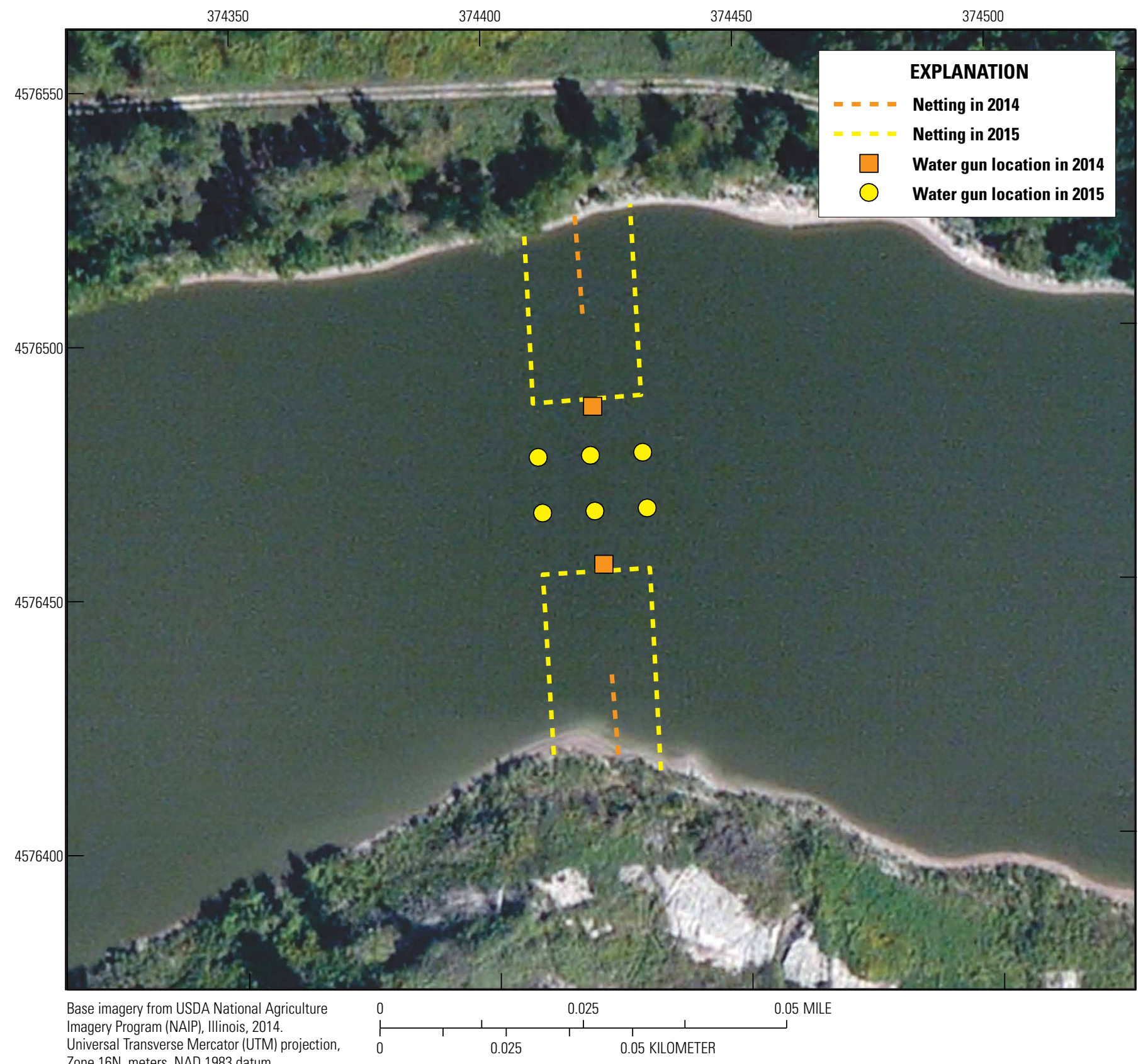

Figure 4. Location of the water guns and netting to create a simulated lock approach channel within the backwater pond in 2014 and 2015. 
Each water gun was suspended from an anchored, $6 \times 6-\mathrm{ft}$ aluminum pontoon float and controlled by a HotShot (2014) or BigShot (2015) controller tethered to a laptop computer. Air was supplied to each gun by a high-pressure, high-volume air compressor (rated at 5,000 lb/in ${ }^{2}$ and 81 standard cubic feet per minute) during 2014 and two high-pressure reciprocating compressors (rated at $5,000 \mathrm{lb} / \mathrm{in}^{2}$ and 100 standard cubic feet per minute), linked in tandem, during 2015.

Hydrophones were used to determine the increase in pressure at specific distances from the water guns. These piezoelectric sensors measure the impact of the blast front moving through the water on a quartz crystal, which produces an electrical voltage in proportion to the pressure increase. The sensors used were OYO Geospace Hydrophones, modified by Instantel, with a sensitivity of $0.0237 \mathrm{lb} / \mathrm{in}^{2}$. They were sampled at a rate of 8,000 to 32,000 samples per second (sps) by an Instantel Blasting Seismograph.

The UBS are also piezoelectric sensors used to determine the increase in pressure from the water guns. The impact of the blast front moving through the water produces an electrical voltage on a tourmaline crystal in proportion to the pressure increase. The sensors used were PCB Piezotronics Underwater Blast Sensors being sampled at 8,000 to $32,000 \mathrm{sps}$ by a National Instruments data acquisition system linked to a computer running National Instruments Labview Signal Express software. These sensors have a sensitivity of $0.02 \mathrm{lb} / \mathrm{in}^{2}$.

The UBS and hydrophones both monitor pressure, but they have different operational ranges. UBS are rated to $1,000 \mathrm{lb} / \mathrm{in}^{2}$ and are suitable for collecting high-pressure data created at closer distances to the water guns. The hydrophones are only rated to $47 \mathrm{lb} / \mathrm{in}^{2}$, but are much more sensitive to the $1-10-1 \mathrm{~b} / \mathrm{in}^{2}$ range and are therefore more suitable to record pressures generated at distances greater than $30 \mathrm{ft}$.

Geophones are mechanical sensors that record the magnitude of ground motion using calibrated weights and springs. A metal weight moving within a coil of wire produces a voltage equivalent to the motion at the geophone. This voltage is transmitted through wires to the seismograph.

Three-component geophones, with frequency of 10 hertz $(\mathrm{Hz})$, coil resistance of $395 \mathrm{ohms}$, and sensitivity of 27.5 volts per meter per second $(\mathrm{V}) /(\mathrm{m} / \mathrm{s})$, were used in 2014 connected to the seismograph. The seismograph sampled these geophones at a rate of one measurement every 0.125 millisecond for a period of 8 seconds (s). The seismograph was connected to a computer running Geometrics Seismodule Controller.

For all setups, the water guns were placed in a fixed position and depth and fired at a constant pressure. Sensors were suspended in the water column at a fixed distance and depth and moved sequentially in the water surrounding the water gun to produce the pressure maps. Three to five water gun shots were taken at each point location, and the maximum value for all shots was recorded. The arithmetic mean values of the maximum pressure values recorded at each position were used in the pressure map figures.

\section{August 2014 Study}

The August 2014 study consisted of collecting water pressure and ground velocity data while two 80 -in ${ }^{3}$ water guns were fired in order to map the pressures and ground velocities produced by the water guns.

Two 80 -in ${ }^{3}$ water guns were positioned along a northsouth line and centered east-west and north-south in the pond, with the water guns suspended horizontally so that the ejection ports were facing north-south, at a depth of about $6 \mathrm{ft}$ bws. The water guns were separated by $100 \mathrm{ft}$, with the north gun approximately $100 \mathrm{ft}$ from the north shore and the south gun approximately $100 \mathrm{ft}$ from the south shore (fig 4). Data were collected over 3 days while the water guns were being fired simultaneously, every $10 \mathrm{~s}$ at a firing pressure of $1,550 \mathrm{lb} / \mathrm{in}^{2}$. Twelve hydrophones were suspended at $1-\mathrm{ft}$ increments from 1 to $12 \mathrm{ft}$. Certain areas of the pond are shallower than $12 \mathrm{ft} \mathrm{(fig.} \mathrm{3),} \mathrm{and} \mathrm{the} \mathrm{water} \mathrm{column} \mathrm{is} \mathrm{not}$ sufficient to suspend the full length of the hydrophone string. Such circumstances caused the deeper hydrophones to pile up at the bottom of the pond, resulting in data that are not true representations of the water pressure at the supposed hydrophone depths. For two lines of hydrophone positions, water depths were recorded from a winch as it lowered a cinderblock, used to weight the end of the hydrophone string, into the water. Based on these winch depth values, it could be determined if the water was deep enough to support the whole hydrophone string. The resulting pressure maps were edited so that potentially bad data would not be shown because they may not represent the true pressures at these depths. During data collection, hydrophones were advanced across the pond following an approximate 10-ft grid spacing (fig. 5). Five shots were recorded at each position. Measurements were made in a square-wave-type pattern, with the hydrophones being advanced to the northern or southern extent of the study area. The hydrophones were then moved $10 \mathrm{ft}$ in the east-west direction to establish a new north-south sampling section. This pattern was repeated until the hydrophones became too close to the exclusion zone, a 15 -ft radius around the water guns, to be operated safely.

Four geophones were arranged on the sandy shore, pointed north, with 10-ft grid spacing between them (fig. 5). The geophones were color coded to more easily distinguish between them; herein they will be referenced by their color. The transverse component was oriented east-west and the longitudinal component was oriented north-south. The vertical component was oriented perpendicular to the ground surface. The geophone arrangement remained the same throughout the study. Ten shots were recorded every hour during working hours (approximately 7 a.m. to 5 p.m.) over 3 days.

Equipment was located using real-time kinematic (RTK) global positioning systems (GPS). Each position of the buoys supporting the hydrophone and a central point on the water gun barge were georeferenced. Position data were collected using Universal Transverse Mercator (UTM) coordinates. 


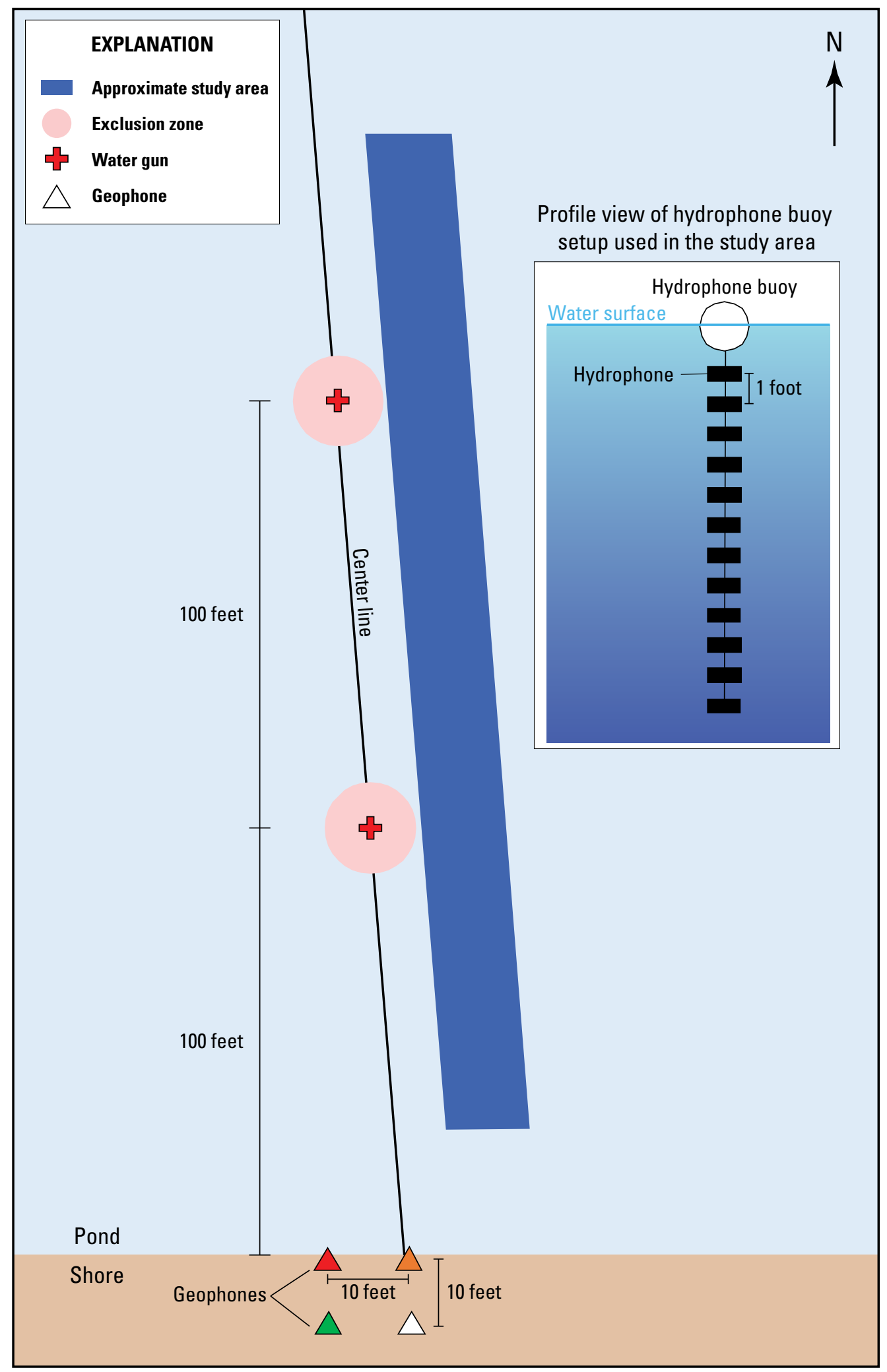

Figure 5. Diagram of the equipment setup for the August 2014 study. Geophones are all the same type of instrument but color coded to distinguish among them (not to scale). 


\section{May 2015 Study}

During the May 2015 study, pressure data were collected from the firing of either one (single-gun shot) or two (doublegun shot) 100 -in ${ }^{3}$ water guns in order to map a simulated lock channel.

A passage was created using six 100 -in ${ }^{3}$ water guns arranged in a three by two grid (fig. 4). Netting was secured around the north and south sides of the grid to create a channel roughly $110 \mathrm{ft}$ wide and $52 \mathrm{ft}$ long. This passage simulated the typical width of a lock channel in the CAWS (U.S. Army Corps of Engineers, 2016). The water guns were suspended $6 \mathrm{ft}$ bws, with the ejection ports facing north-south. The water guns were approximately $132 \mathrm{ft}$ from shore, separated by $26 \mathrm{ft}$ east-west and $35 \mathrm{ft}$ north-south. Data were collected for the center two water guns (fig. 4). The hydrophones were suspended at 1-ft increments from 1 to $12 \mathrm{ft}$ bws. Winch measurements of depth to the bottom of the pond were made at each hydrophone group position. Based on the recorded winch-measurement depths, corrections to the pressure maps were made as needed. During data collection, hydrophones were moved to cover the area east of the water guns following an approximate $10-\mathrm{ft}$ grid spacing. Measurements were made in a square-wave-type pattern, with the hydrophones advanced east-west across the eastern part of the simulated lock approach channel (fig. 6). The hydrophones were then moved approximately $10 \mathrm{ft}$ south to establish a new east-west-trending sampling section. This pattern was repeated until the hydrophones reached the southern edge of the simulated lock channel. The water guns used in 2015 were larger than those used in 2014, so an exclusion zone had not yet been established. In order to prevent any damage to the hydrophones, and also owing to the inability to access the center channel area by boat because of steel support cabling, UBS were used to collect pressure measurements from a radius of $26 \mathrm{ft}$ inward. Three shots were recorded with the north gun and three shots with both guns at 2,000 lb/in². During hydrophone operation, the UBS were stationed approximately $40 \mathrm{ft}$ north of the north gun and were not moved.

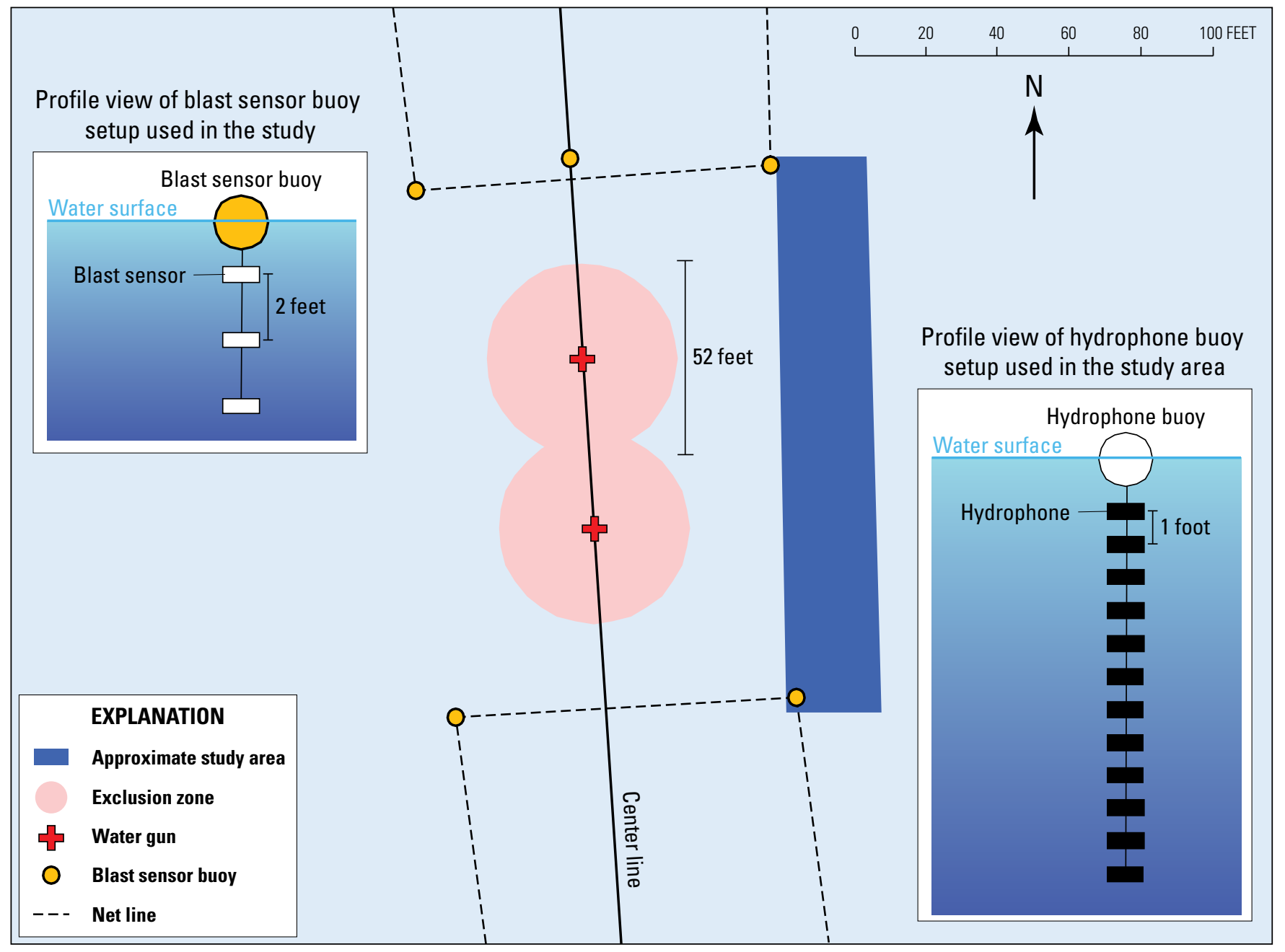

Figure 6. Diagram of the hydrophone setup for the May 2015 study. 
After the completion of the hydrophone measurements, the UBS survey began. The UBS were used to map the rest of the pressure barrier on the eastern part of the simulated lock approach channel (from the centerline to $26 \mathrm{ft}$ east of the centerline) (fig. 7). Three north-south lines were measured, one along the centerline, one $13 \mathrm{ft}$ east of the centerline, and one $26 \mathrm{ft}$ east of the centerline. Twelve shots were taken at an operating pressure of $2,000 \mathrm{lb} / \mathrm{in}^{2}$ : six shots with the north gun (three with the UBS at 1,3 , and $5 \mathrm{ft}$ bws and three with the UBS at 7,9, and $11 \mathrm{ft}$ bws) and then six shots with both guns firing simultaneously (three with the UBS at 1, 3, and $5 \mathrm{ft}$ bws and three with the UBS at 7, 9, and $11 \mathrm{ft}$ bws). Winch measurements were unable to be made at UBS group positions owing to the steel stabilizing cables surrounding the simulated lock channel, which prevented the boat from entering the grid. After each shot sequence, the UBS were moved approximately $13 \mathrm{ft}$ along the survey line.

Equipment was located using RTK GPS. When GPS accuracy declined from insufficient satellites, equipment position was noted in relation to other geolocated equipment and recorded in a field notebook. A position was noted for each buoy supporting the hydrophone string and UBS string and a central point on the water gun barge. Position data were collected using UTM coordinates.

Processed location data were integrated with the average maximum values obtained from each data point. These data were contoured by using Esri ArcMAP (ver. 10.3, http:// www.esri.com). A kernel smoothing with barriers algorithm was used to smooth the data and create pressure maps within the hydrophone and UBS boundaries on each side of the water gun. This kernel interpolation model fits a first order polynomial, within specified overlapping neighborhoods, to produce the mapping output, limiting instability by using methods similar to ridge regression to estimate the regression coefficients. Because this technique fits a surface to the majority of the data points, the surface does not always represent the exact values of the measured point data recorded by the hydrophones and UBS.

The hydrophone data closest to the gun were collected within a few feet of the UBS data farthest away from the gun. As the distance to the water guns became nearer, the equipment transitioned from hydrophone to UBS, locating the UBS and

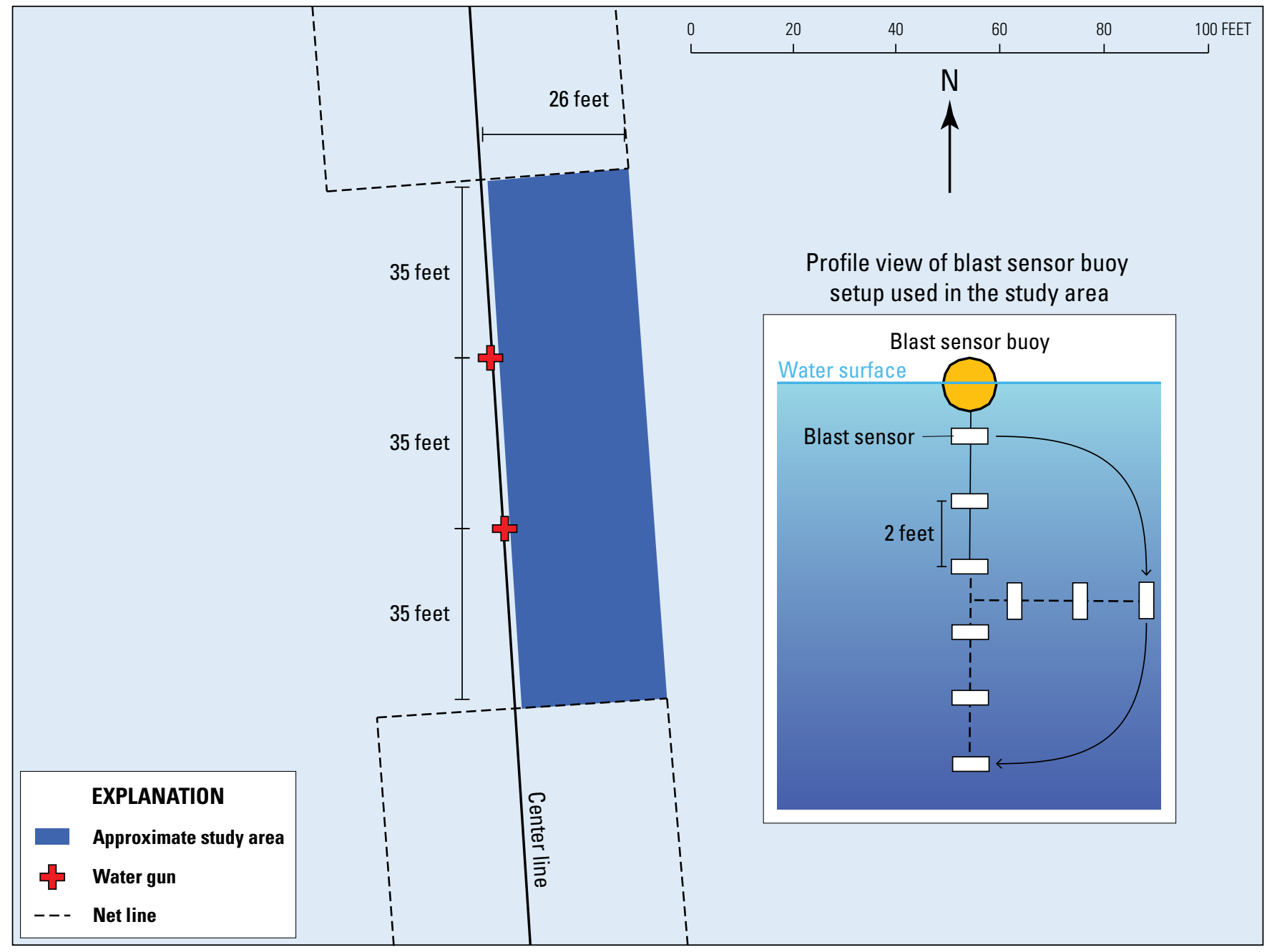

Figure 7. Diagram of the underwater blast sensor setup for the May 2015 study. 
hydrophones within a few feet of each other and allowing for comparison. However, the pressure values measured by these two sets of instruments were not consistent. An experiment was set up to create a side-by-side comparison. The hydrophones and UBS were both suspended next to each other at the northeast corner of the simulated lock channel in order to perform a comparison between the two types of instruments. Ten shots were recorded, with five measurements from the UBS at 1,3 , and $5 \mathrm{ft}$ bws and five measurements from the UBS at 7,9 , and $11 \mathrm{ft}$ bws. A comparison between the maximum recorded pressures at the various depths for the two instruments is displayed in figure 8. The hydrophones and UBS are better correlated at depths of $9 \mathrm{ft}$ bws or greater, where they are located below the water gun.

The UBS are rated to $1,000 \mathrm{lb} / \mathrm{in}^{2}$, whereas the hydrophones are rated to $47 \mathrm{lb} / \mathrm{in}^{2}$. Pressures recorded during the surveys were on the lower end of the UBS recording spectrum, below the fifth percentile, so they are likely to be less reliable than the hydrophone data.

\section{Water Pressure and Ground Vibrations Induced by Water Guns}

The following sections of the report contain selected pressure maps and velocity graphs of the backwater pond, grouped by recording instrument. Pressure maps show data points that are derived from an arithmetic mean of the 3-5 maximum pressure values recorded at each position (appendix 1, figs. 1-1 through $1-8)$. The velocity graphs show the absolute maximum velocities of each component that were recorded. Signals from water gun firings were recorded by seismographs and datasets are cataloged as plan-view and cross-sectional maps in appendix 1. Microsoft Excel files and raw digital data files are described in appendixes 2 and 3, respectively. All data files are available at http://dx.doi. org/10.3133/sir20165098.

\section{August 2014 Study}

\section{Pressure Field}

The August 2014 pressure field results for the hydrophones in figures 9 and 10 are presented as plan-view and vertical contour maps at increasing depths. Pressures in these plots range from less than $1 \mathrm{lb} / \mathrm{in}^{2}$ to approximately $13.7 \mathrm{lb} / \mathrm{in}^{2} 25 \mathrm{ft}$ away from the water guns. The $5-\mathrm{lb} / \mathrm{in}^{2}$ contour is noted in the figures as well as the location of the water guns and hydrophones.

Higher pressures are found closest to the water guns and decrease with increasing distance from the water guns (figs. 9, 10). The pressure value is maximized around a depth of $5 \mathrm{ft}$ bws at $13.7 \mathrm{lb} / \mathrm{in}^{2}$, approximately $25 \mathrm{ft}$ (horizontal distance) from the water guns. This depth also includes the greatest extent of the $5-\mathrm{lb} / \mathrm{in}^{2}$ target value (fig. $9 \mathrm{C}$ ). The maps indicate that over the same distance from the water guns, there is a greater decrease in pressure below the water guns than above (figs. 9, 10B, $C$ ). The 1- and 2-ft-depth-bws plots

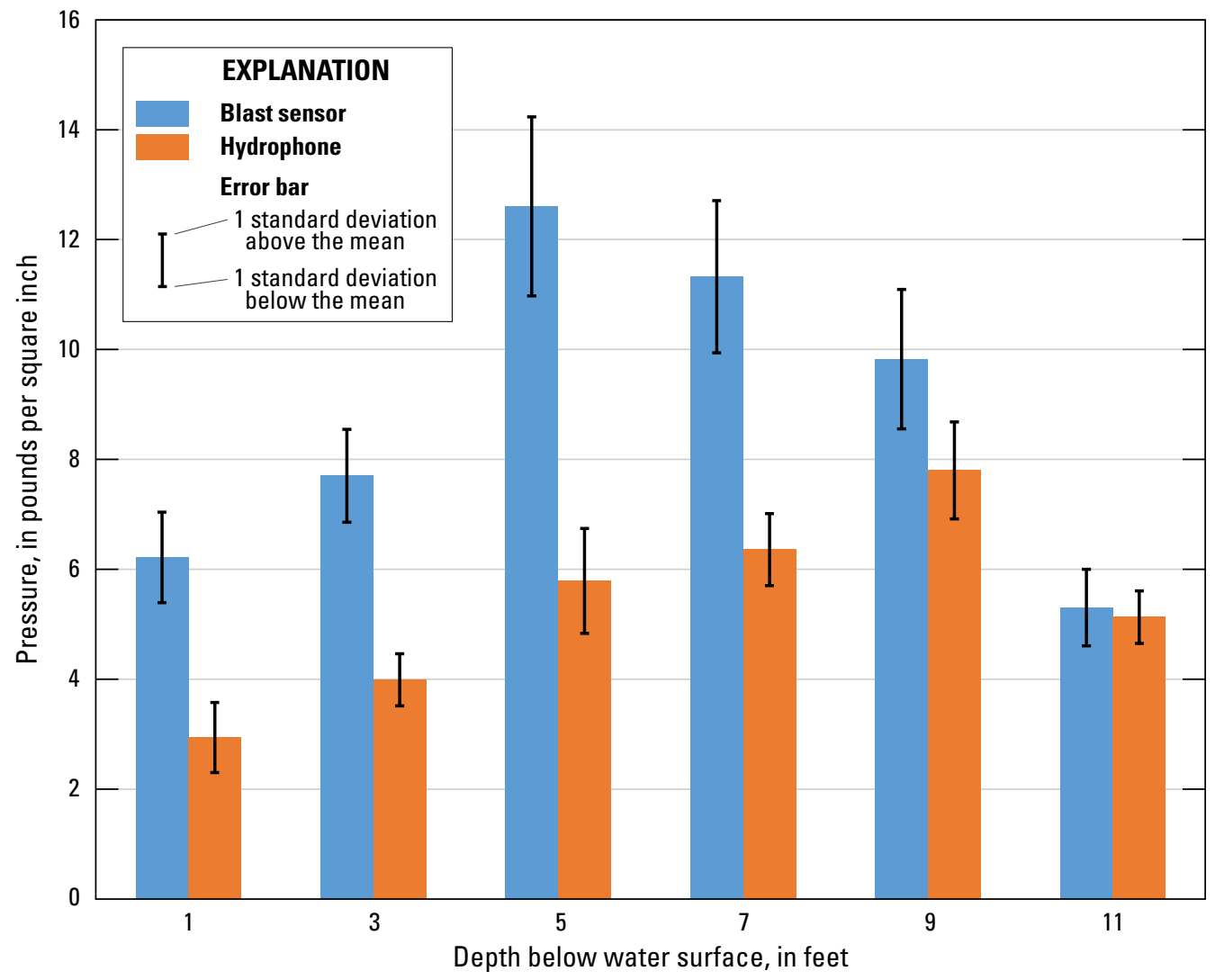

Figure 8. Comparison of the recorded pressures at various depths between blast sensors and hydrophones. 


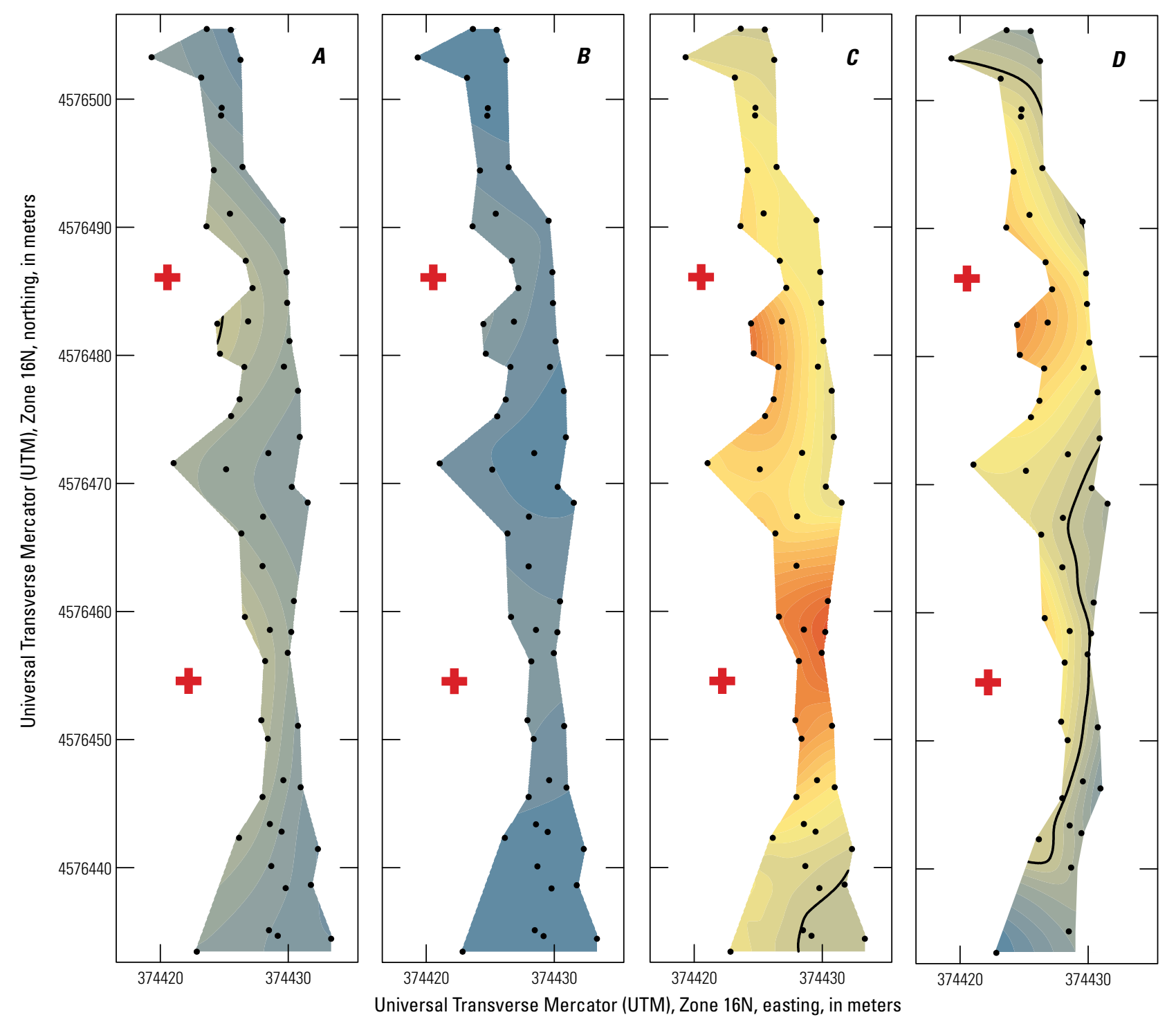

EXPLANATION
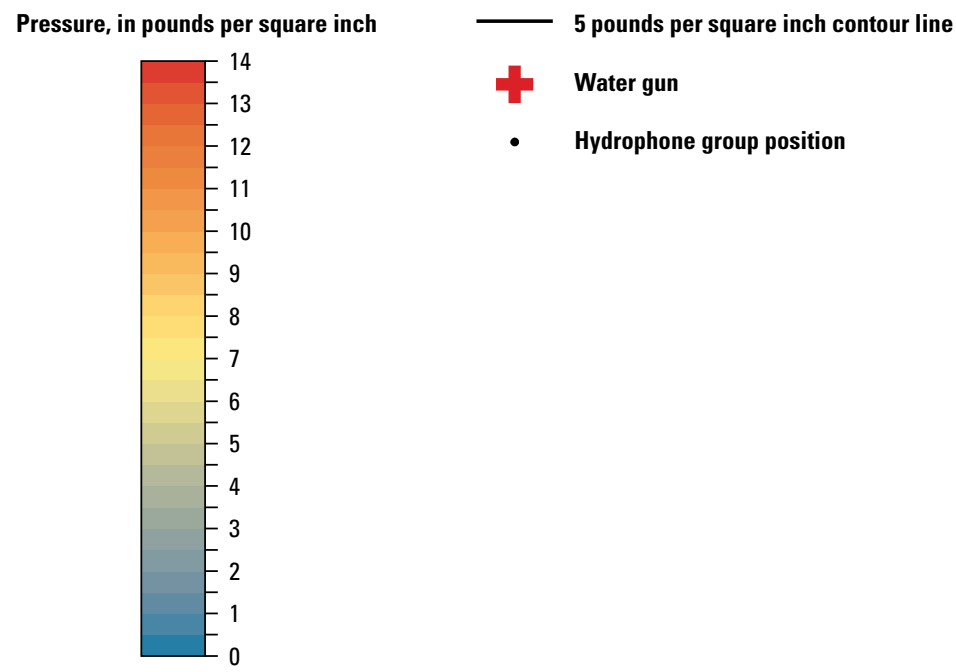

Figure 9. Pressure maps from two 80 -cubic-inch water guns fired at 1,550 pounds per square inch, for measurements recorded by hydrophones located at depths of 1 foot $(A), 2$ feet $(B), 5$ feet $(C)$, and 8 feet $(D)$ below the water surface of a backwater pond at Morris, Illinois, August 2014. 


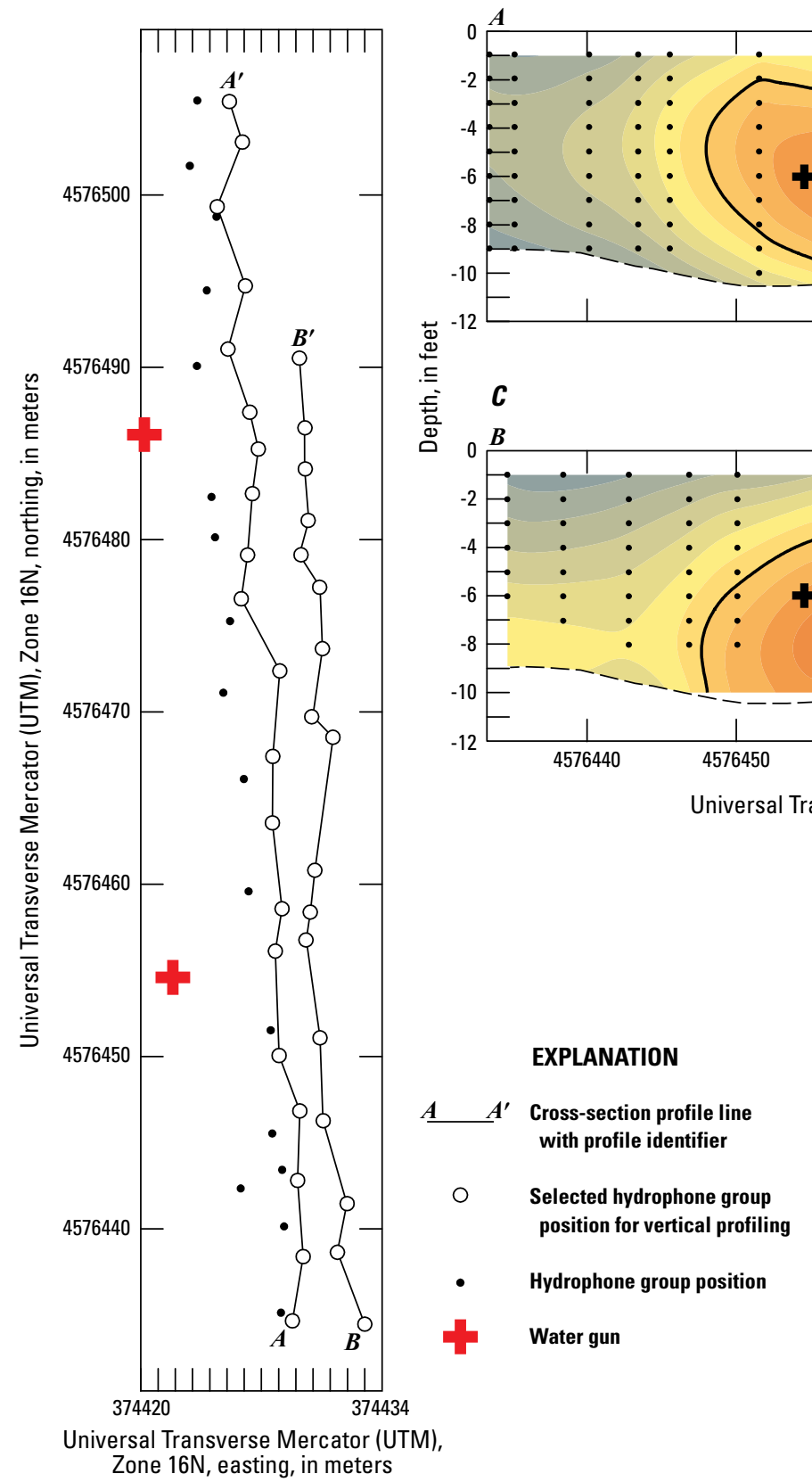

EXPLANATION
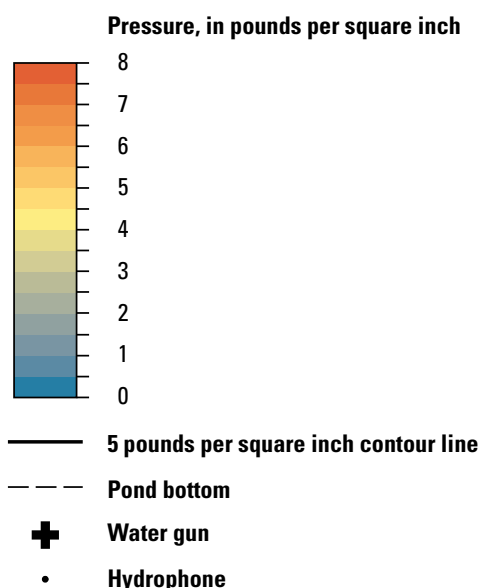

Figure 10. Plan-view map and cross-sectional pressure maps from two 80 -cubic-inch water guns fired at 1,550 pounds per square inch. Plan-view map $(A)$ depicts the cross-section lines for the $A-A^{\prime}(B)$ and $B-B^{\prime}(C)$ cross-sectional pressure maps for the backwater pond study area at Morris, Illinois, August 2014.

(fig. $9 A, B$ ) have some of the lowest pressure values recorded. The 1-ft-depth-bws plot recorded slightly higher pressures because of interference from the water surface. The $5-1 b / \mathrm{in}^{2}$ target value pressure field is a roughly north-south-oriented elongated sphere with a segment of decreased diameter between the guns.

Relative standard deviations of the five-shot groupings at depths of 1, 5, and $12 \mathrm{ft}$ bws for the August 2014 experiment are shown in figure 11. Standard deviations for this grouping decrease in close proximity to the water gun firing port. Variation is lower at the depths where the highest pressures were recorded (approximately $5 \mathrm{ft}$ bws) and increases as horizontal and vertical distances from the water guns increase.

\section{Ground Velocity}

Geophone data were collected during a series of regular interval water gun shots (one shot every $10 \mathrm{~s}$ ) with intermittent periods of no shots, over a period of 3 days. Ten velocity values were recorded every hour that personnel were present (usually 10 hours per day) during water gun firing. Ground velocity was measured using three-component geophones mounted on the 


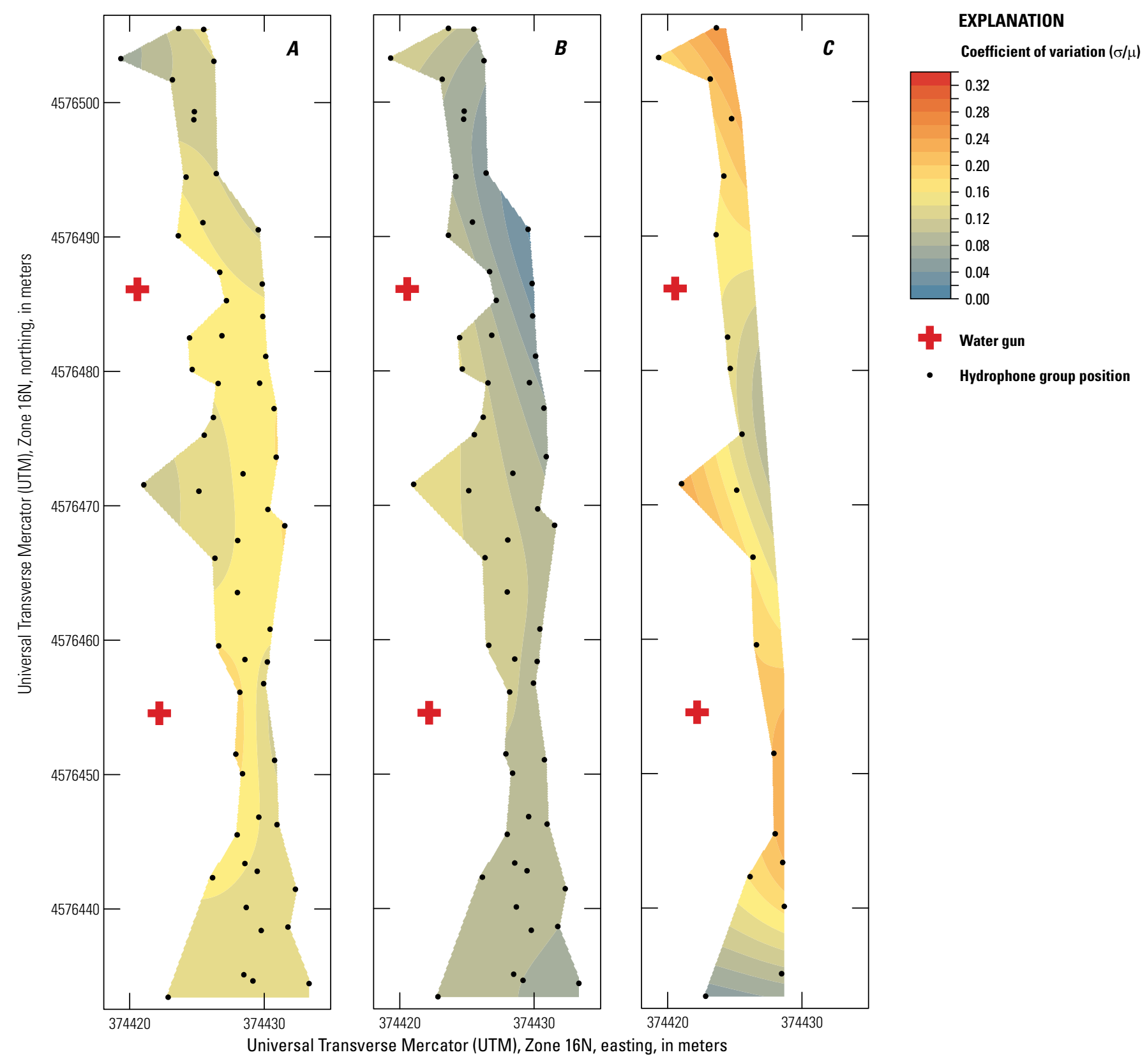

Figure 11. Spatial distribution of the relative standard deviation for each five-shot grouping, measured at depths of 1 foot $(A), 5$ feet $(B)$, and 12 feet $(C)$ below the water surface for experiments in August 2014.

sandy shore of the pond. The geophones were deployed in a grid along the edge of the water and along the centerline, with 10 -ft grid spacing between each geophone, and oriented such that the longitudinal component of each geophone was pointing north. Each geophone was color coded with identifying tape for easier reference: red was northwest, orange was northeast, green was southwest, and white was southeast (fig. 5). The maximum velocities recorded for all geophones during the experiment were 0.013 inches per second (in/s) of vertical velocity and $0.031 \mathrm{in} / \mathrm{s}$ of horizontal (longitudinal) velocity.

Some data points were removed from the dataset owing to aberrant sources. Suspicious points that did not fit in with the overall consistent velocity trend underwent a waveform analysis, comparing them to controls (those from shots within the trend), to determine any inconsistencies that would classify them as outliers and thus give reason for removal. A large group of outlying points were grouped together at shot number 106-112 owing to compressor failure because the compressor had to be shut down shortly after the recording of these values. Analysis of the waveforms of other points displayed high frequency noise from people walking or from boat motors nearing the geophones and causing constructive or destructive interference. The data point at shot 10 had an incomplete waveform owing to the recording starting too late and missing the peak velocity. 
Velocity values remained generally consistent as the shot number increased (fig. 12): $0.0067 \mathrm{in} / \mathrm{s}$ in the transverse direction, $0.031 \mathrm{in} / \mathrm{s}$ in the longitudinal direction, and $0.013 \mathrm{in} / \mathrm{s}$ in the vertical direction. Air expelled by the water guns remained at a consistent pressure above $1,550 \mathrm{lb} / \mathrm{in}^{2}$; however, there appears to be a cyclic pattern to the horizontal component velocities recorded by the geophones. This cyclic pattern may be a result of the geophones picking up vibrations from the compressor as it turned on and off.
The geophones located along the edge of the water (orange and red) recorded larger horizontal velocities than their counterparts $10 \mathrm{ft}$ from the edge of the water (white and green) (fig. 13). Geophones located in line with the water guns recorded larger velocities than their counterparts offset $10 \mathrm{ft}$ from the centerline. The orange geophone, located at the edge of the water and along the water gun centerline, recorded the highest velocity $(0.031 \mathrm{in} / \mathrm{s}$ in the longitudinal component) of the study. The component recording the highest velocity is
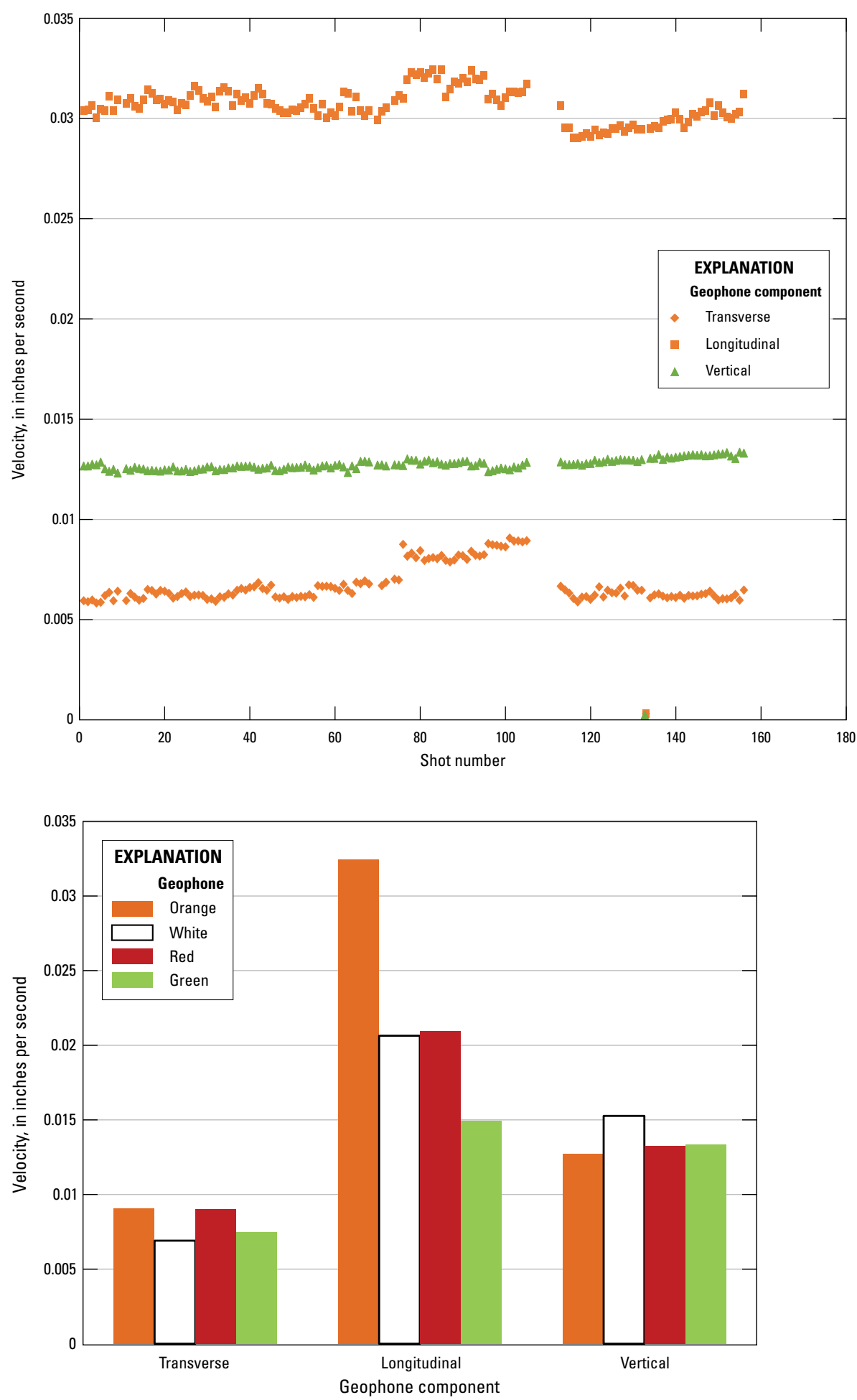

Figure 12. Geophone component maximum velocity from each shot, recorded during water gun firing at Morris, Illinois, August 2014. Color designates which geophone the component was from (orange, northeast; green, southwest).

Figure 13. Maximum velocities recorded at each geophone, by component, during the August 2014 water gun firing at Morris, Illinois. 
consistent between geophones: the longitudinal component recorded the fastest velocities whereas the transverse component recorded the slowest velocities.

\section{May 2015 Study}

\section{Pressure Field-Single-Gun Shot}

Based on hydrophone and UBS transects closest to the water guns (fig. 14), the May 2015 pressure field results for the hydrophones in figures 15 and 16 are presented as vertical and plan-view contour maps, at increasing depths. Pressures in these plots range from less than $1 \mathrm{lb} / \mathrm{in}^{2}$ to approximately $56.7 \mathrm{lb} / \mathrm{in}^{2}$. The $5-\mathrm{lb} / \mathrm{in}^{2}$ contour, as well as the location of the guns and hydrophones, is noted in the figures.

Data next to the water gun at a depth of $5 \mathrm{ft}$ bws showed both the highest pressure (approximately $56.7 \mathrm{lb} / \mathrm{in}^{2}$ ) and the greatest radial extent of the $5-\mathrm{lb} / \mathrm{in}^{2}$ target value, covering the entire north-south part and 80 percent of the east-west part of the study area (figs. $15 A, 16$ ). The $5-1 \mathrm{~b} / \mathrm{in}^{2}$ target value had a greater extent north-south than east-west owing to the orientation of the water gun ports. Pressure increases with depth to about $5 \mathrm{ft}$ bws, where it begins to decrease with depth. Pressure then increases again around a depth of $10 \mathrm{ft}$ bws along the $5 \mathrm{lb} / \mathrm{in}^{2}$ contour line, possibly owing to the presence of the bottom of the pond (fig. 15A). Pressures are greatest next to the water gun and decrease farther away (figs. 15, 16). Data above and below a depth of $5 \mathrm{ft}$ bws show smaller extents of the $5-\mathrm{lb} / \mathrm{in}^{2}$ target value. The overall shape of the $5-\mathrm{lb} / \mathrm{in}^{2}$ pressure field produced by a single water gun is that of an elongated sphere oriented north-south.

\section{Pressure Field-Double-Gun Shot}

The pressure field results for the hydrophones in figures 17 and 18 are presented as vertical and plan-view contour maps at increasing depths. Pressures in these plots range from less than $1 \mathrm{lb} / \mathrm{in}^{2}$ to approximately $57.4 \mathrm{lb} / \mathrm{in}^{2}$. The $5-\mathrm{lb} / \mathrm{in}^{2}$ contour is noted in the figures as well as the location of the guns and hydrophones.

Data next to the water guns at a depth of $5 \mathrm{ft}$ bws showed both the highest pressure (approximately $57.4 \mathrm{lb} / \mathrm{in}^{2}$ ) and the greatest radial extent of the $5-\mathrm{lb} / \mathrm{in}^{2}$ target value, covering the entire north-south part and most of the east-west part of the study area (figs. $17 A, 18$ ). The $5-\mathrm{lb} / \mathrm{in}^{2}$ target value had a greater extent north-south than east-west owing to the orientation of the water gun ports. Pressure increases with depth to about $5 \mathrm{ft}$ bws, where it begins to decrease with depth. Pressures are greatest next to the water guns and decrease farther away (figs. 17, 18). Data above and below a depth of $5 \mathrm{ft}$ bws show smaller extents of the $5-\mathrm{lb} / \mathrm{in}^{2}$ target value (fig. 18). The overall shape of the $5-\mathrm{lb} / \mathrm{in}^{2}$ pressure field produced by firing two water guns simultaneously is that of an elongated sphere oriented north-south. However, pressures at depths of $3,5,7$, and $9 \mathrm{ft}$ bws deviate from this overall pressure field shape (appendix 1, figs. 1-6B through

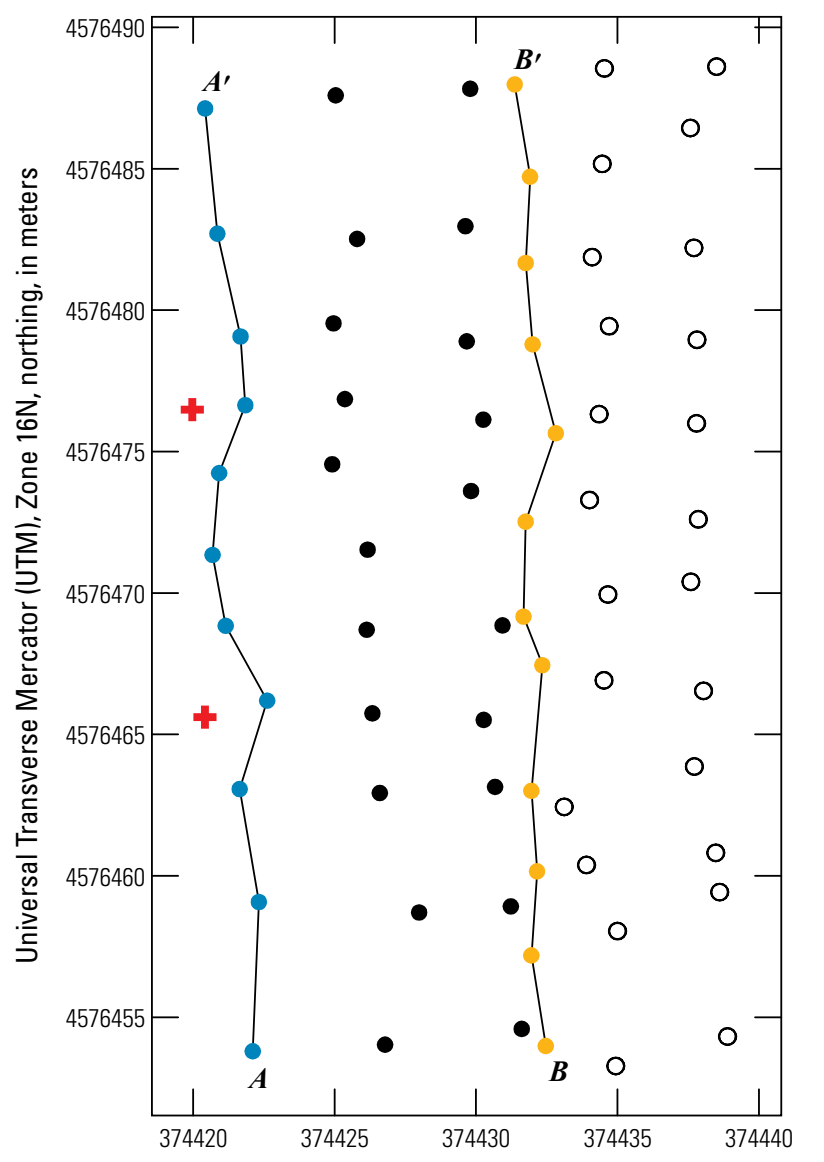

Universal Transverse Mercator (UTM), Zone 16N, easting, in meters

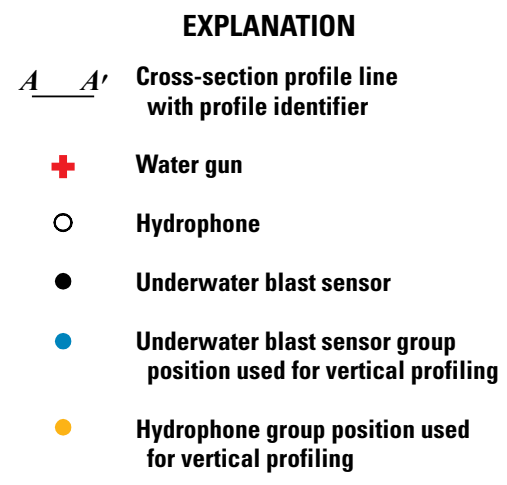

Figure 14. Location map of the underwater blast sensor $\left(A-A^{\prime}\right)$ and hydrophone $\left(B-B^{\prime}\right)$ lines chosen for vertical pressure map profiling, May 2015.

$1-6 E)$. A projection of higher pressure extends from between the two water guns eastward, as can be seen in the deviation of the $5-1 b / i^{2}$-target-value contour (fig. 18). This is most likely due to the interaction of each water gun's pressure field as it expands. Standard deviation values for the May 2015 study were not calculated because only three shots were recorded at each point. 


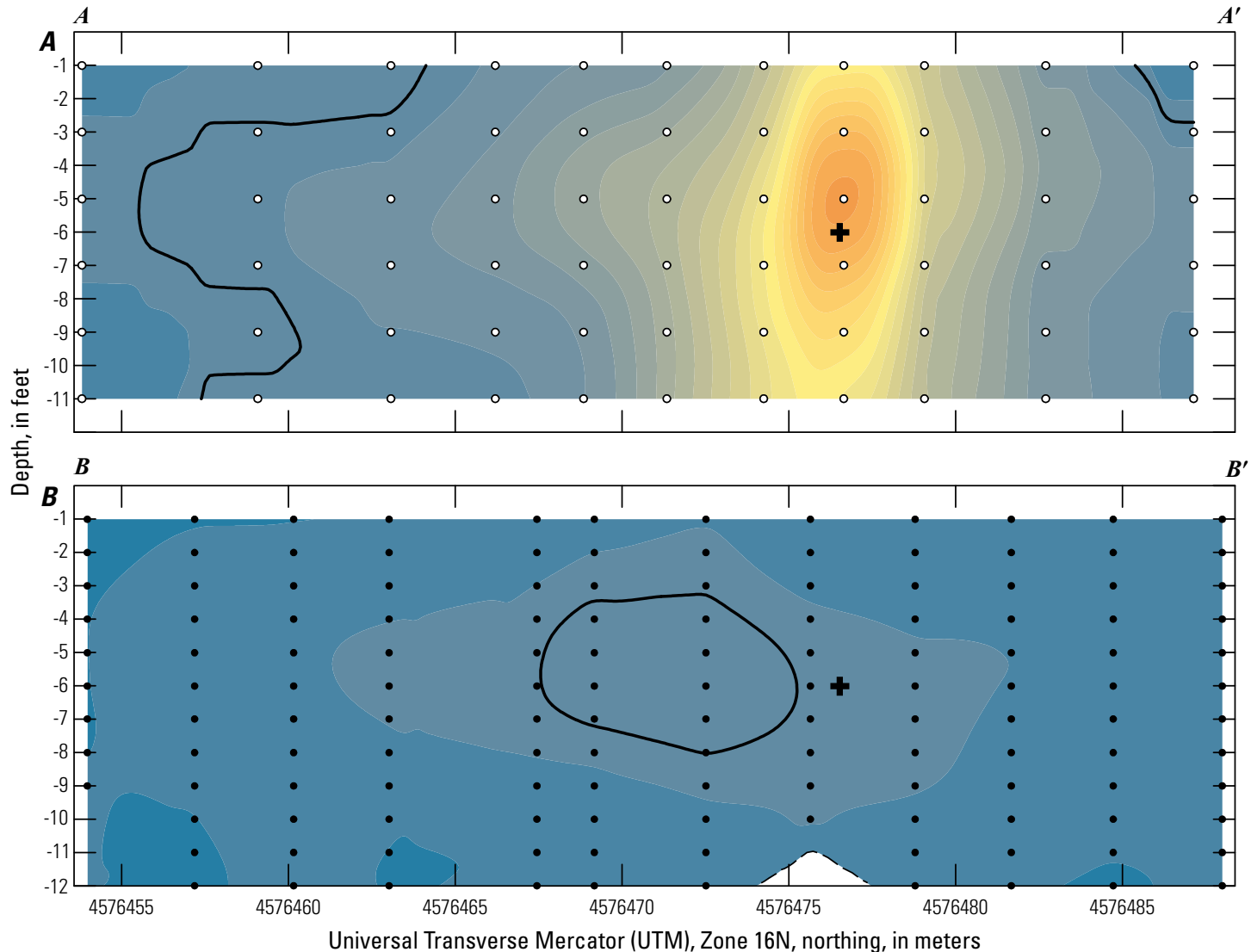

Figure 15. Cross-sectional pressure maps from a 100-cubic-inch water gun fired at 2,000 pounds per square inch, for measurements from underwater blast sensor $(A)$ and hydrophone $(B)$ profile lines.

Water gun marked was the one fired.
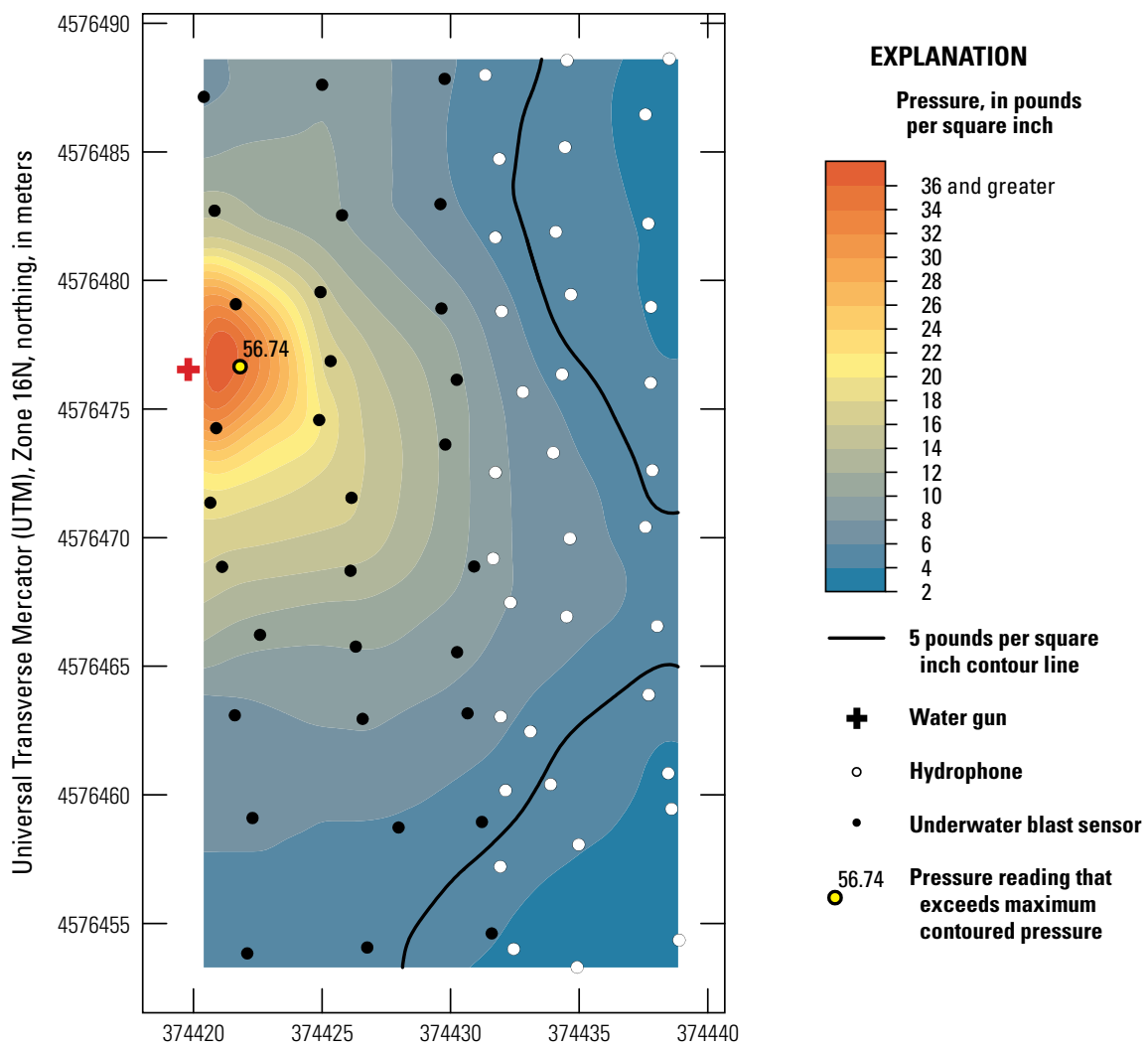

\section{EXPLANATION}

Pressure, in pounds per square inch

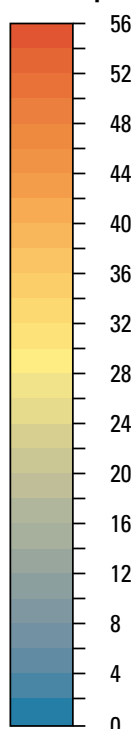

\section{5 pounds per square inch contour line \\ - - Pond bottom \\ + Water gun \\ $\circ \quad$ Underwater blast sensor}

- Hydrophone
Figure 16. Pressure map from a 100 - cubic-inch water gun fired at 2,000 pounds per square inch, for measurements at a depth of 5 feet below the water surface of a backwater pond at Morris, Illinois, May 2015. 


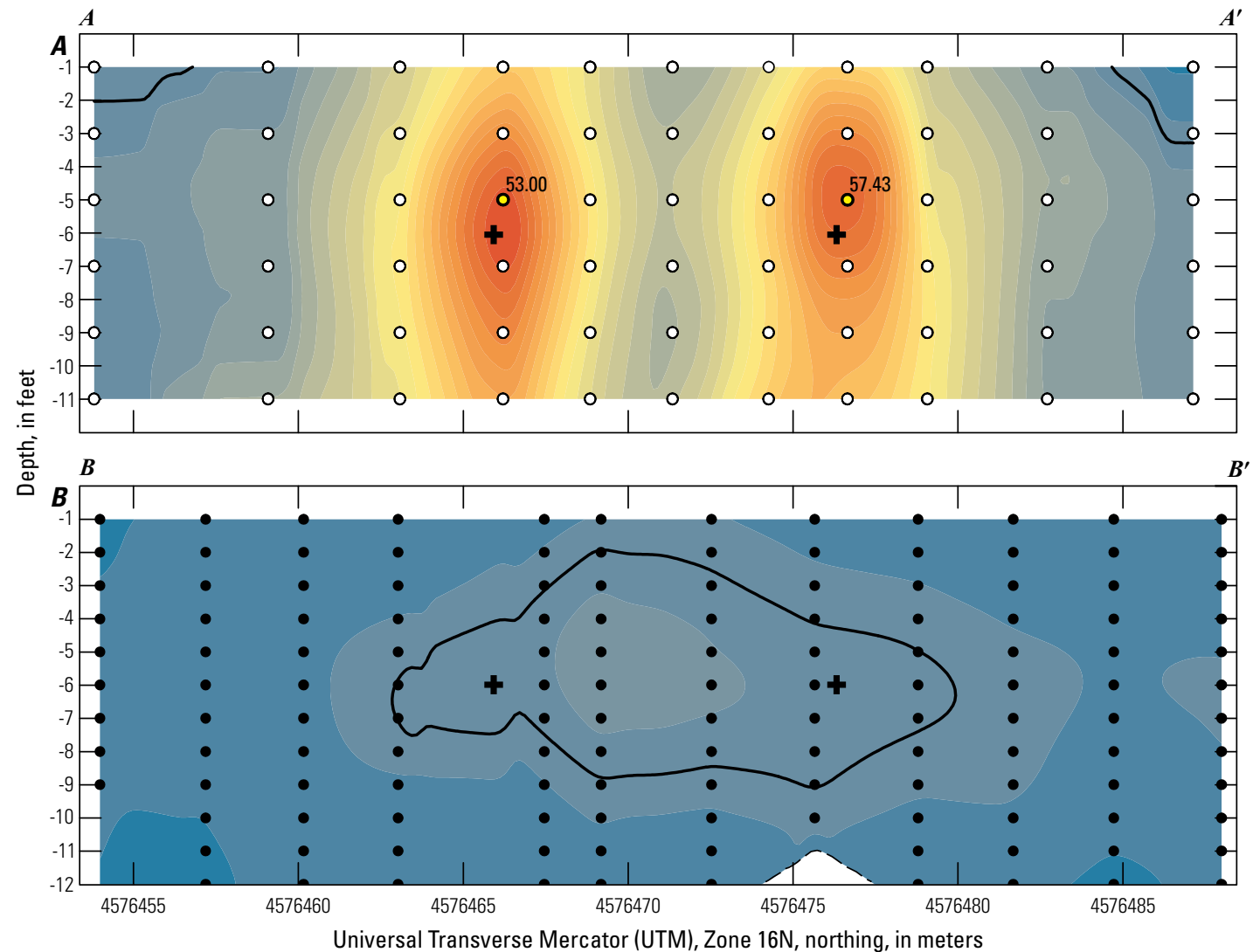

Figure 17. Cross-sectional pressure maps from two 100 -cubic-inch water guns fired at 2,000 pounds per square inch, for measurements from underwater blast sensor $(A)$ and hydrophone $(B)$ lines closest to the water guns, May 2015.

Figure 18. Pressure map from two 100-cubic-inch water guns fired at 2,000 pounds per square inch, for measurements at a depth of 5 feet below the water surface of a backwater pond at Morris, Illinois, May 2015.
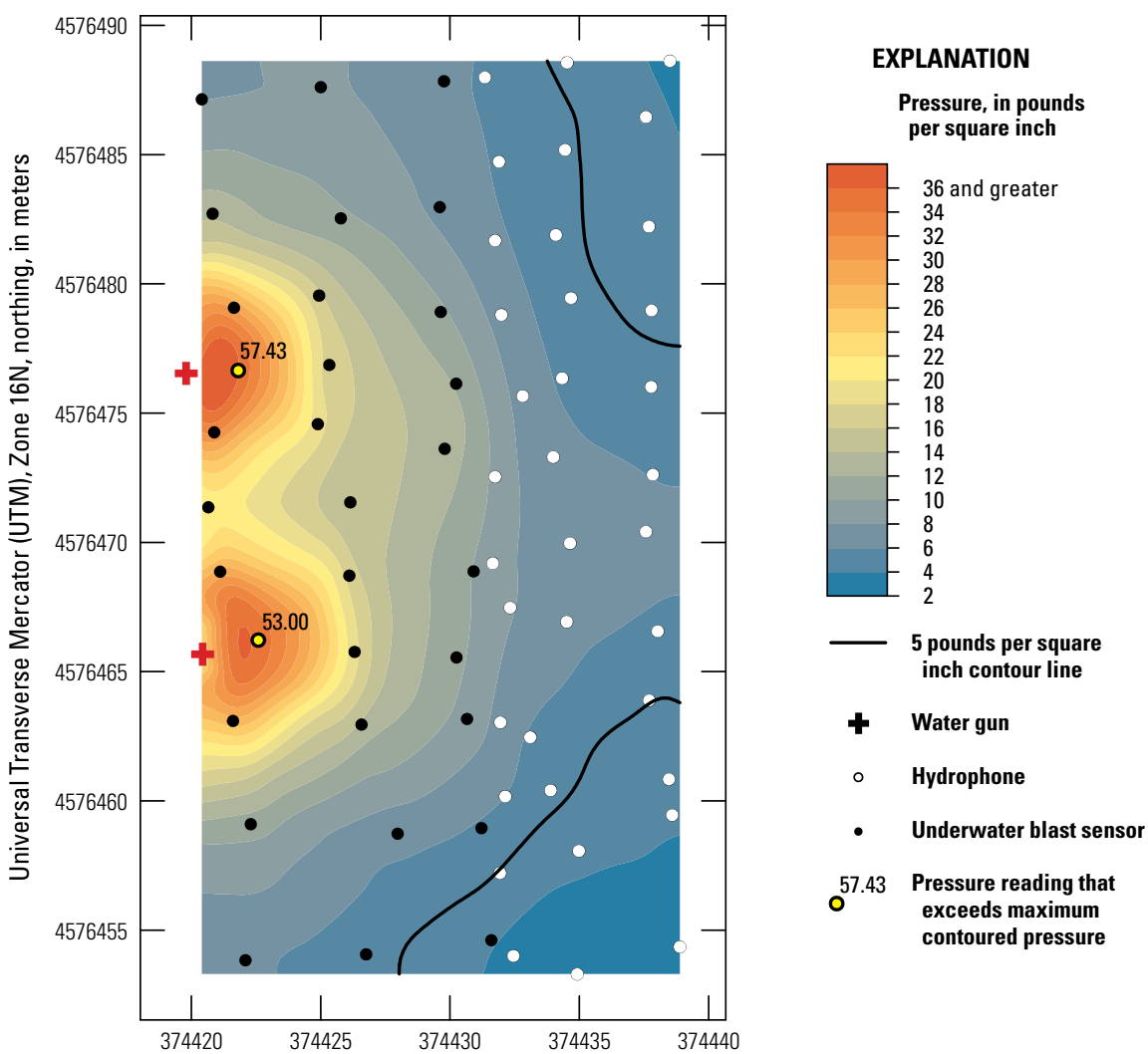

Universal Transverse Mercator (UTM), Zone 16N, easting, in meters

\section{EXPLANATION}

Pressure, in pounds per square inch

44 and greater 40 36 32 28 24 20 16 12 8 0

$\begin{array}{cl}- & \begin{array}{c}5 \text { pounds per square } \\ \text { inch contour line }\end{array} \\ - & \text { Pond bottom } \\ + & \text { Water gun } \\ 0 & \begin{array}{c}\text { Underwater blast } \\ \text { sensor }\end{array} \\ -\quad & \text { Hydrophone } \\ 57.43 \quad \begin{array}{c}\text { Pressure reading that } \\ \text { exceeds maximum } \\ \text { contoured pressure }\end{array}\end{array}$
contoured pressure 


\section{Summary}

Two studies, one each in August 2014 and May 2015, were performed to evaluate the physical characteristics of the pressure field in the water and the ground velocity on land created by water guns fired in a backwater pond of the Illinois River at a quarry near Morris, Illinois. Pressure data were collected by using blast-rated hydrophones in 2014, whereas both hydrophones and underwater blast sensors (UBS) were used to evaluate pressure in 2015. Geophones were used to collect ground velocity data in 2014 .

The purpose of the August 2014 study was to measure and map the pressure field created by two 80 -in ${ }^{3}$ water guns fired simultaneously every $10 \mathrm{~s}$. The recorded ground velocities remained consistent over time, were greater at the edge of the water and decreased farther from the water's edge, and produced a maximum recorded horizontal velocity of $0.031 \mathrm{in} / \mathrm{s}$. The magnitude of the pressure field produced by an $80-$ in $^{3}$ water gun was greatest at a depth of $5 \mathrm{ft}$ bws, producing a pressure field shaped like an elongated sphere, with the greatest extent of the $5-\mathrm{lb} / \mathrm{in}^{2}$ target value extending across the majority of the study area.

The May 2015 study measured and mapped the pressure field created by one and two simultaneously fired $100-\mathrm{in}^{3}$ water guns. Pressures were recorded both inside and outside of the constructed simulated lock approach channel. The magnitude of the pressure field was the greatest at a depth of $5 \mathrm{ft}$ bws with the greatest extent of the $5-\mathrm{lb} / \mathrm{in}^{2}$ target value extending across the majority of the study area. The shape of the pressure field was more consistent with depth during double-gun shots, however, the $5-\mathrm{lb} / \mathrm{in}^{2}$ target value contour was not as smooth as compared to the single-gun shots, producing a projection of higher pressure between the two guns.

Despite the two surveys having different water output volumes, separation distances, and firing pressures $-80-\mathrm{in}^{3}, 100 \mathrm{ft}$, and $1,550 \mathrm{lb} / \mathrm{in}^{2}$ compared to $100-\mathrm{in}^{3}, 26 \mathrm{ft}$, and $2,000 \mathrm{lb} / \mathrm{in}^{2}$ - the greatest pressures and extent of the $5-\mathrm{lb} / \mathrm{in}^{2}$ target value were both recorded at a depth of $5 \mathrm{ft}$ bws. At this 5 - $\mathrm{ft}$ depth, maximum recorded pressure was $13.7 \mathrm{lb} / \mathrm{in}^{2}$ (by a hydrophone) in 2014 and $57.4 \mathrm{lb} / \mathrm{in}^{2}$ (by a UBS) in 2015 from firing two water guns simultaneously. The extent of the $5-\mathrm{lb} / \mathrm{in}^{2}$ target value covered the majority of the study area. The overall shape of the pressure fields produced right next to the water guns by firing two water guns simultaneously were north-south-oriented elongated spheres.

\section{References Cited}

Adams, R.F., and Morrow, W.S., 2015, Geophysical investigation of the pressure field produced by water guns at a pond site in La Crosse, Wisconsin: U.S. Geological Survey Open-File Report 2015-1130, 24 p., 1 app., http://dx.doi.org/10.3133/ofr20151130.
Boeger, W.A., Pie, M.R., Ostrensky, A., and Cardoso, M.F., 2006, The effect of exposure to seismic prospecting on coral reef fishes: Brazilian Journal of Oceanography, v. 54, no. 4, p. 235-239.

Ellefsen, K.J., 2003, seg2_edit: A Program for Editing and Manipulating SEG-2 Files: U.S. Geological Survey OpenFile Report 03-141, 11 p., http://pubs.usgs.gov/of/2003/ ofr-03-141/ofr_03_141_508.pdf.

Gordon, J., Gillespie, D., Potter, J., Frantzis, A., Simmonds, M.P., Swift, R., and Thompson, D., 2003, A review of the effects of seismic survey on marine mammals: Marine Technology Society Journal, v. 37, no. 4, p. 16-34.

Gross, J.A., Irvine, K.M., Wilmoth, S., Wagner, T.L., Shields, P.A., and Fox, J.R., 2013, The effects of pulse pressure from seismic water gun technology on Northern Pike: Transactions of the American Fisheries Society, no. 142, no. 5 , p. 1335-1346.

Hirst, A.G., and Rodhouse, P.G., 2000, Impacts of geophysical surveying on fishing success: Reviews in Fish Biology and Fisheries, v. 10, p. 113-118.

Layhee, M.J., Gross, J.A., Parsley, M.J., Romine, J.G., Glover, D.C., Suski, C.D., Wagner, T.L., Sepulveda, A.J., and Gresswell, R.E., 2013, Asian carp behavior in response to static water gun firing: U.S. Geological Survey Fact Sheet 2013-3098, 4 p., http://dx.doi.org/10.3133/ fs20133098.

Romine, J.G., Jensen, N.R., Parsley, M.J., Gaugush, R.F., Severson, T.J., Hatton, T.W., Adams, R.F., and Gaikowski, M.P., 2015, Response of Bighead Carp and Silver Carp to repeated water gun operation in an enclosed shallow pond: North American Journal of Fisheries Management, v. 35, no. 3, p. 440-453, http://dx.doi.org/10.1080/02755947.20 15.1012279 .

Turnpenny, A.W.H., and Nedwell, J.R., 1994, The effects on marine fish, diving mammals and birds of underwater sound generated by seismic surveys: Southampton, United Kingdom, Fawley Aquatic Research Laboratories, Ltd., Report no. FCR 089/94, 50 p.

U.S. Army Corps of Engineers, 2016, Illinois Waterway Locks \& Dams: U.S. Army Corps of Engineers Fact Sheet, 17 p., available at http://www.mvr.usace.army.mil/ Portals/48/docs/CC/FactSheets/IL/IWW\%20Locks\%20 \&\%20Dams\%20-\%202016.pdf.

Wardle, C.S., Carter, T.J., Urquhart, G.G., Johnstone, A.D.F., Ziolkowski, A.M., Hampson, G., and Mackie, D., 2001, Effects of seismic air guns on marine fish: Continental Shelf Research, v. 21, p. 1005-1027. 


\section{Appendix 1. Pressure Maps Produced During All Experiments}

These pressure maps are provided in sequential order by depth of water gun placement to facilitate comparison between the different studies. 

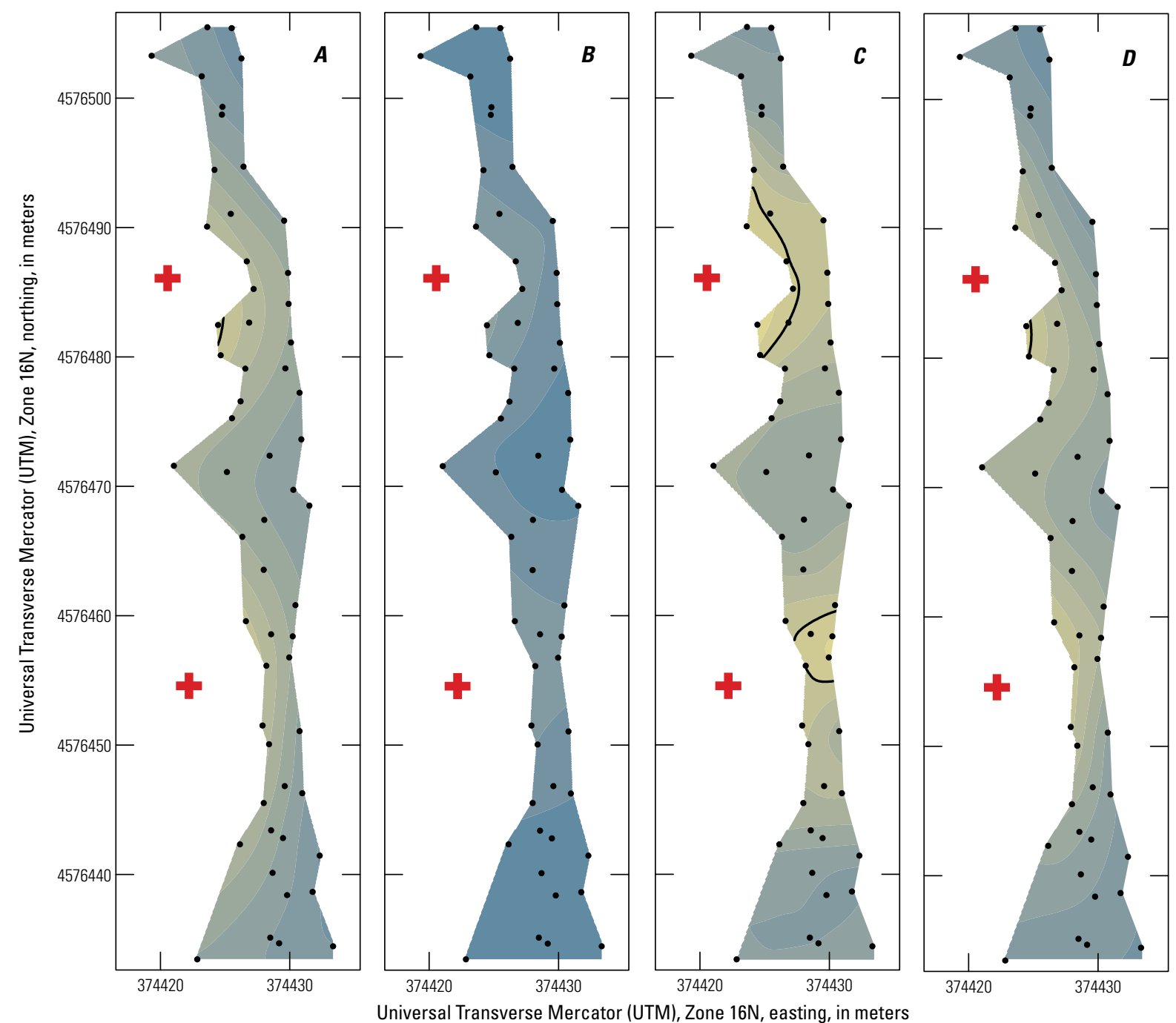

Universal Transverse Mercator (UTM), Zone 16N, easting, in meters

EXPLANATION

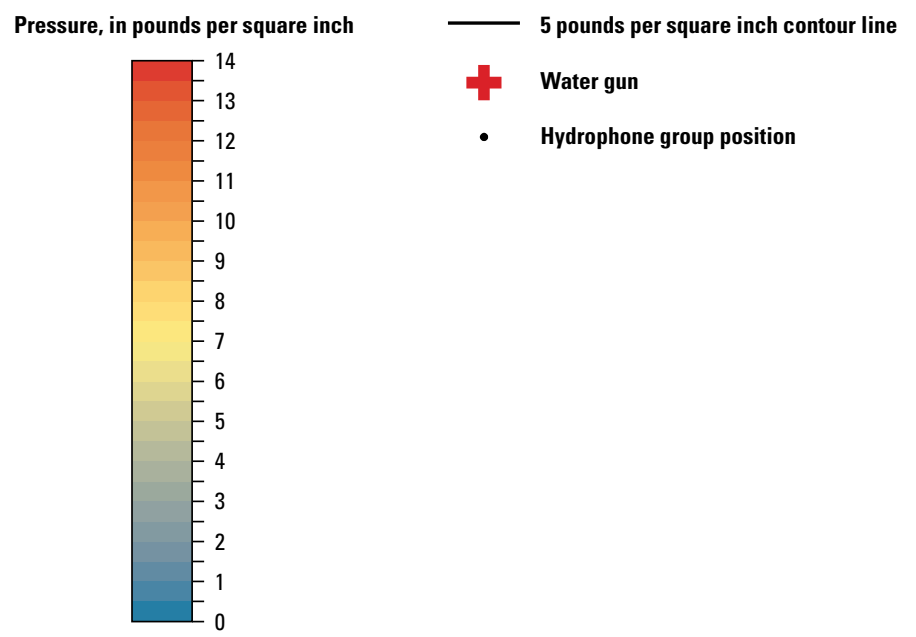

Figure 1-1. Pressure maps from two 80-cubic-inch water guns fired at 1,550 pounds per square inch, for measurements at depths of 1 foot $(A), 2$ feet $(B), 3$ feet $(C)$, and 4 feet $(D)$ below the water surface of a backwater pond at Morris, Illinois, August 2014. 


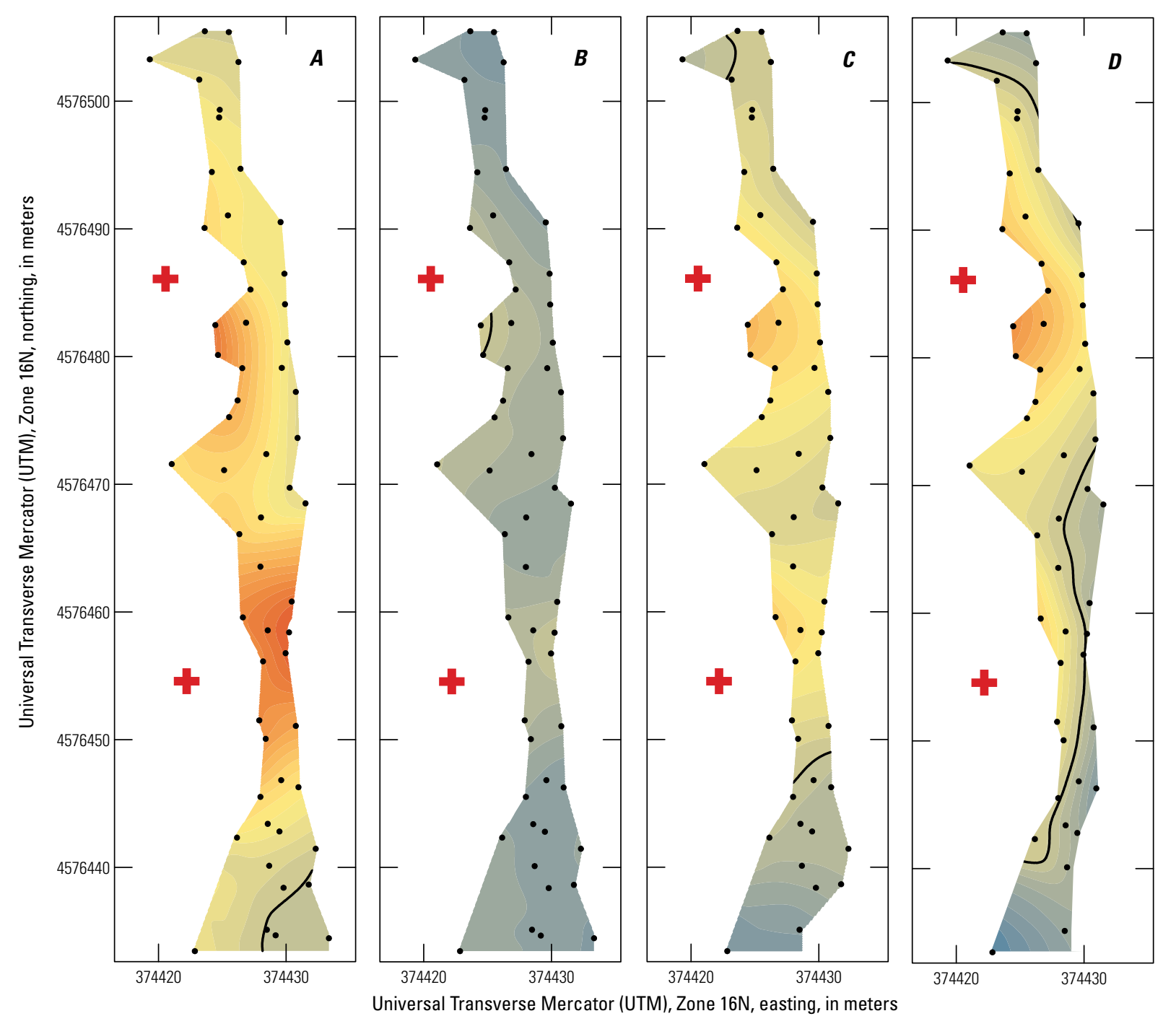

EXPLANATION

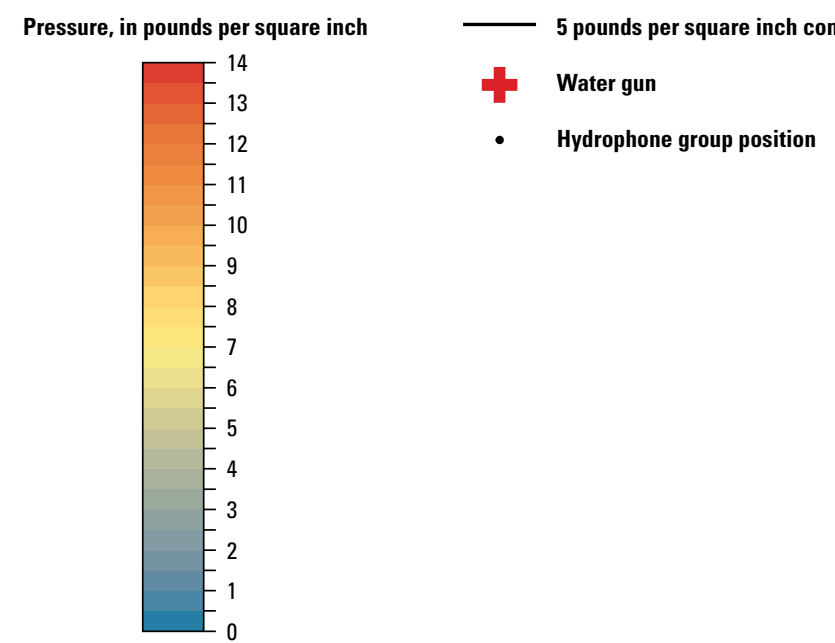

Figure 1-2. Pressure maps from two 80-cubic-inch water guns fired at 1,550 pounds per square inch, for measurements at depths of 5 feet $(A), 6$ feet $(B), 7$ feet $(C)$, and 8 feet $(D)$ below the water surface of a backwater pond at Morris, Illinois, August 2014. 

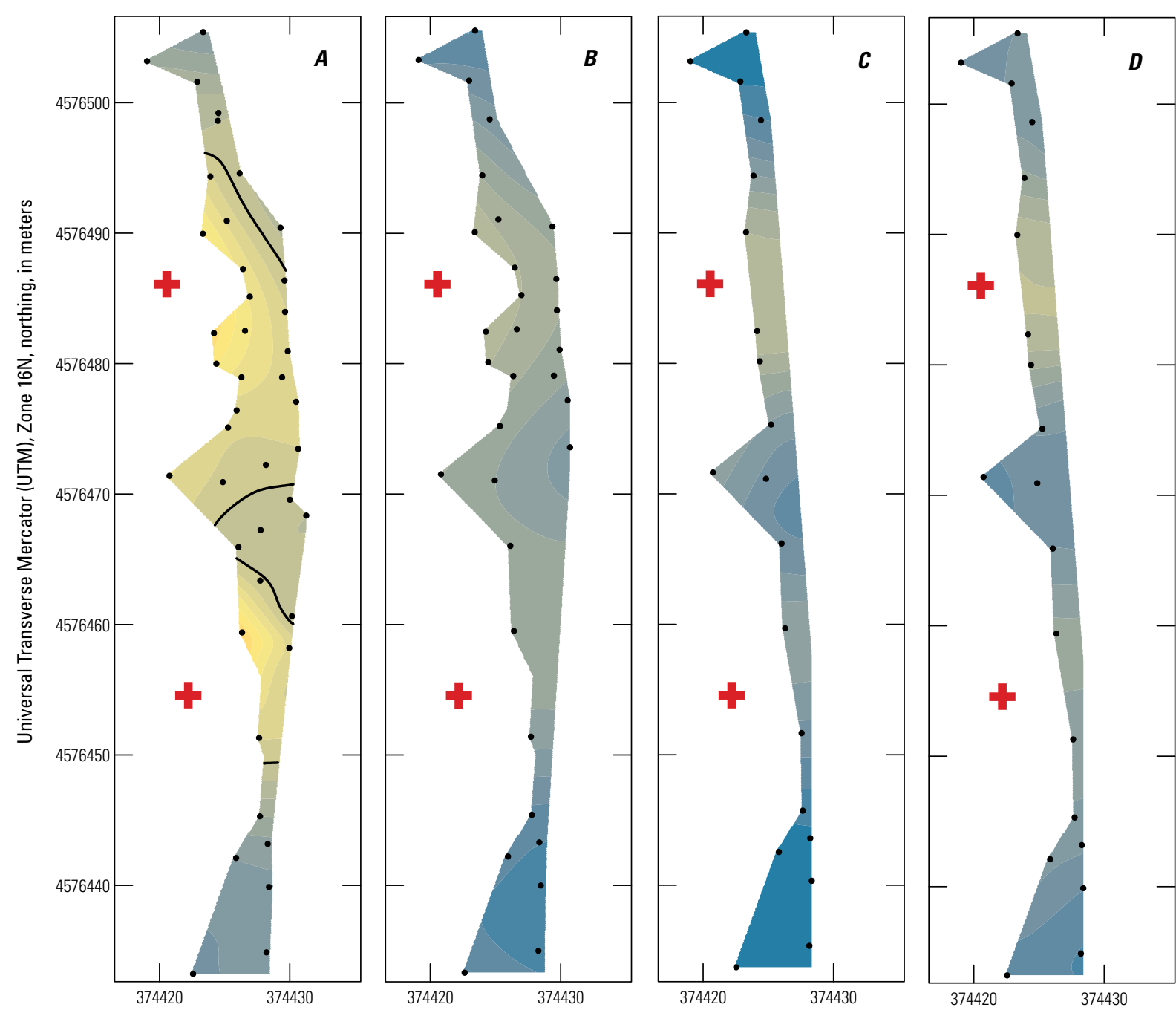

Universal Transverse Mercator (UTM), Zone 16N, easting, in meters

EXPLANATION
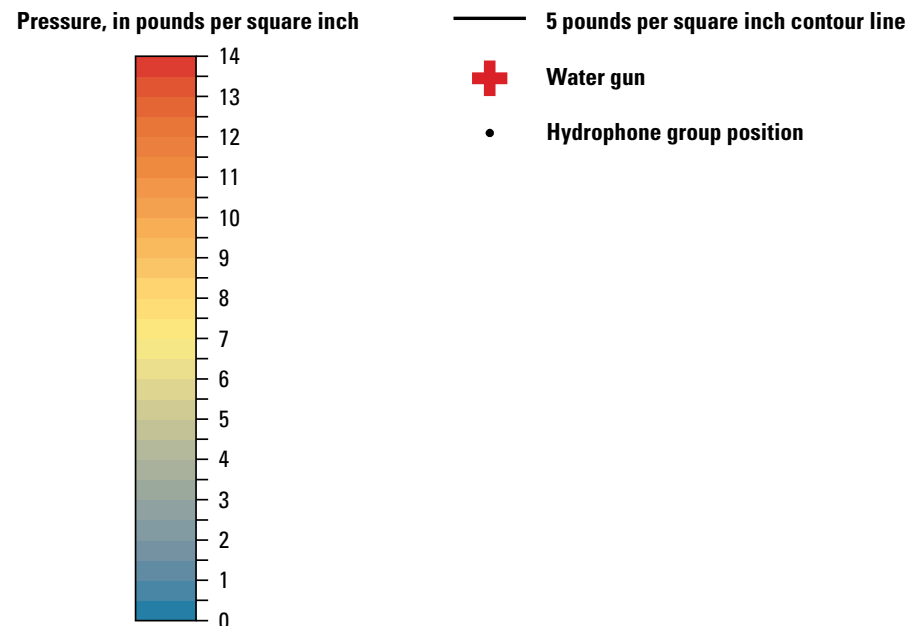

- Hydrophone group position

Figure 1-3. Pressure maps from two 80-cubic-inch water guns fired at 1,550 pounds per square inch, for measurements at depths of 9 feet $(A), 10$ feet $(B), 11$ feet $(C)$, and 12 feet $(D)$ below the water surface of a backwater pond at Morris, Illinois, August 2014. 


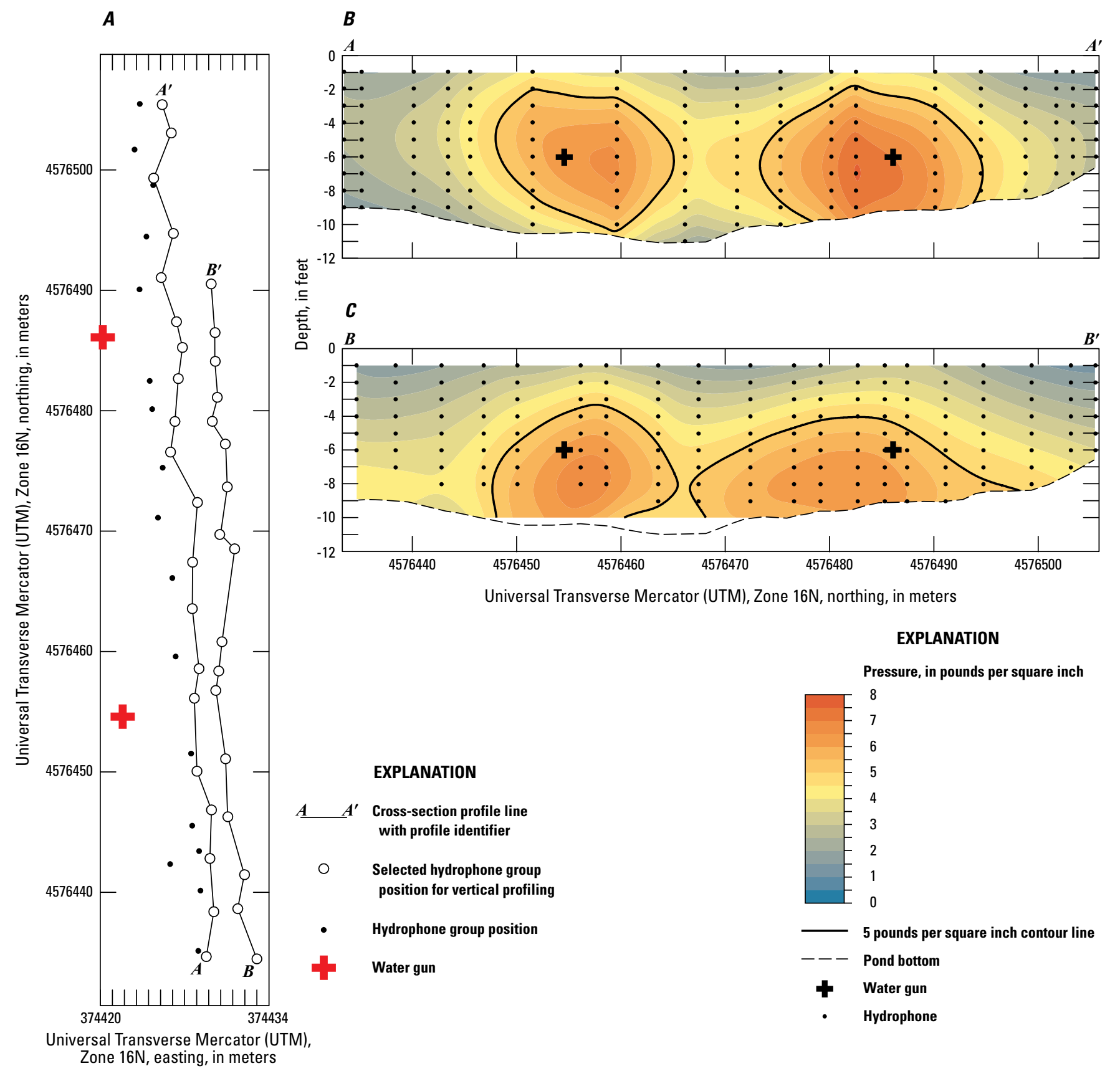

Figure 1-4. Plan-view map and cross-sectional pressure maps from two 80 -cubic-inch water guns fired at 1,550 pounds per square inch. Plan-view map $(A)$ depicts the cross-section lines for the $A-A^{\prime}(B)$ and $B-B^{\prime}(C)$ cross-sectional pressure maps. 

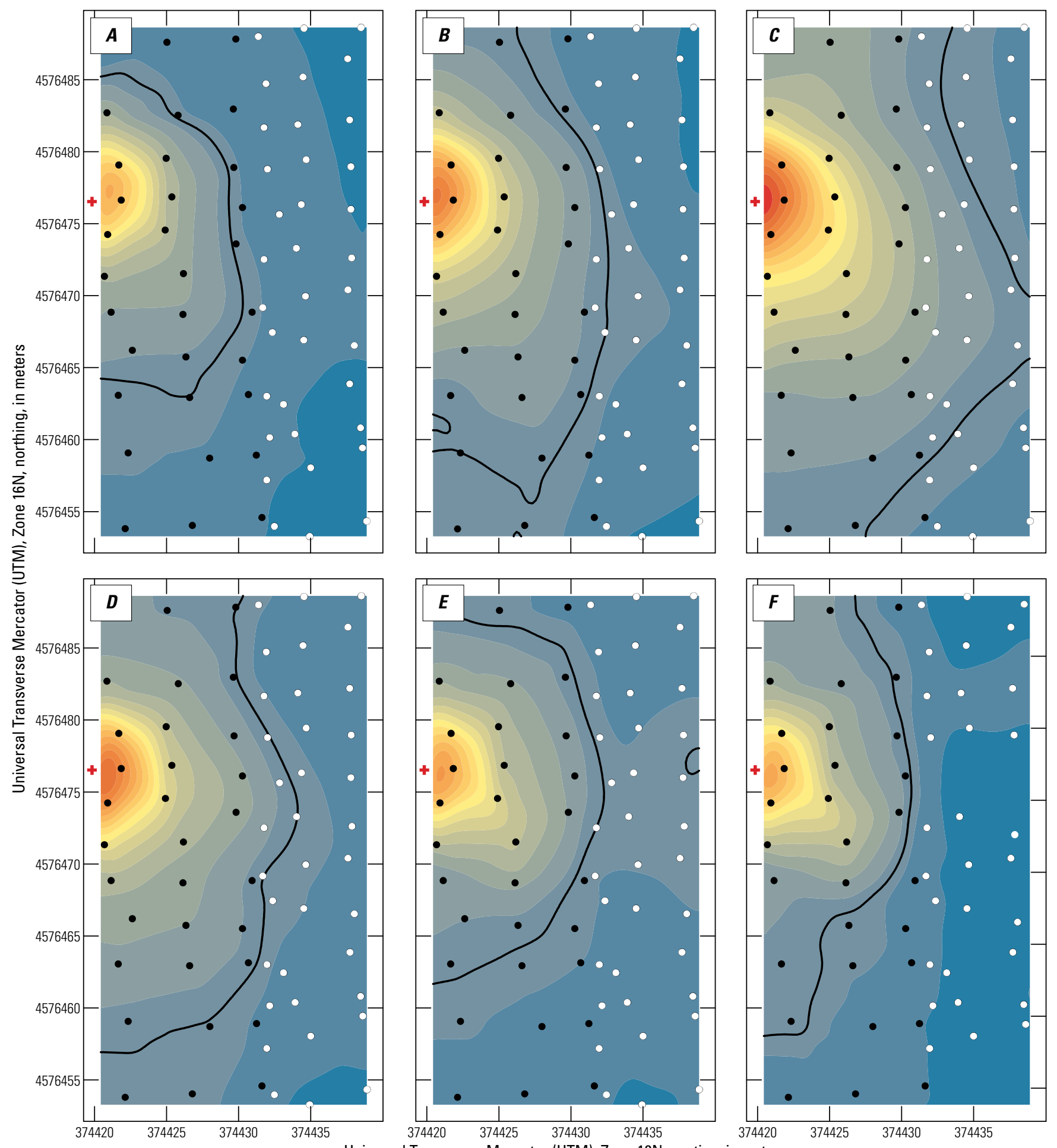

\section{EXPLANATION}
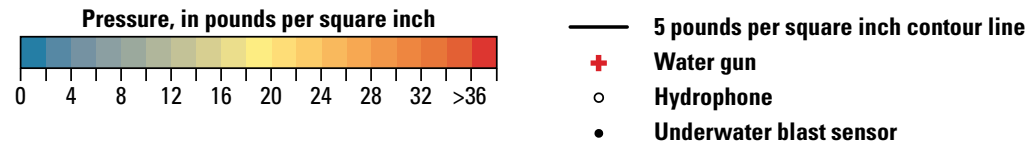

Figure 1-5. Pressure maps from a 100-cubic-inch water gun fired at 2,000 pounds per square inch, for measurements at depths of 1 foot $(A), 3$ feet $(B), 5$ feet $(C), 7$ feet $(D), 9$ feet $(E)$, and 11 feet $(F)$ below the water surface of a backwater pond at Morris, Illinois, May 2015. 

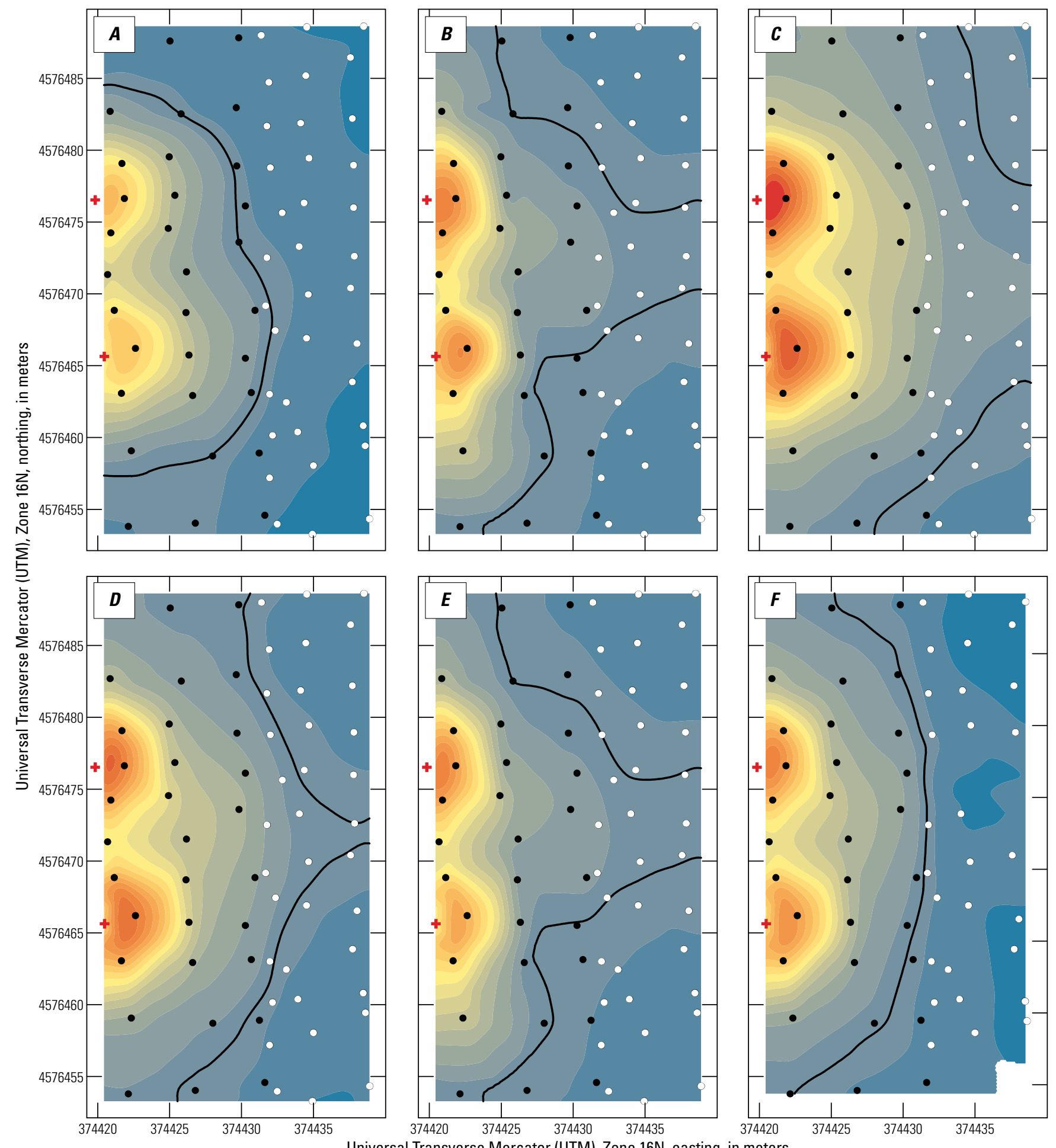

\section{EXPLANATION}

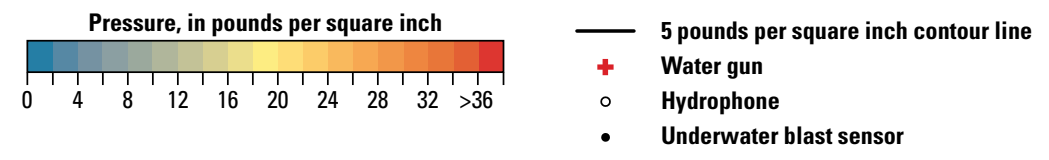

Figure 1-6. Pressure maps from two 100-cubic-inch water guns fired at 2,000 pounds per square inch, for measurements at depths of 1 foot $(A), 3$ feet $(B), 5$ feet $(C), 7$ feet $(D), 9$ feet $(E)$, and 11 feet $(F)$ below the water surface of a backwater pond at Morris, Illinois, May 2015. 


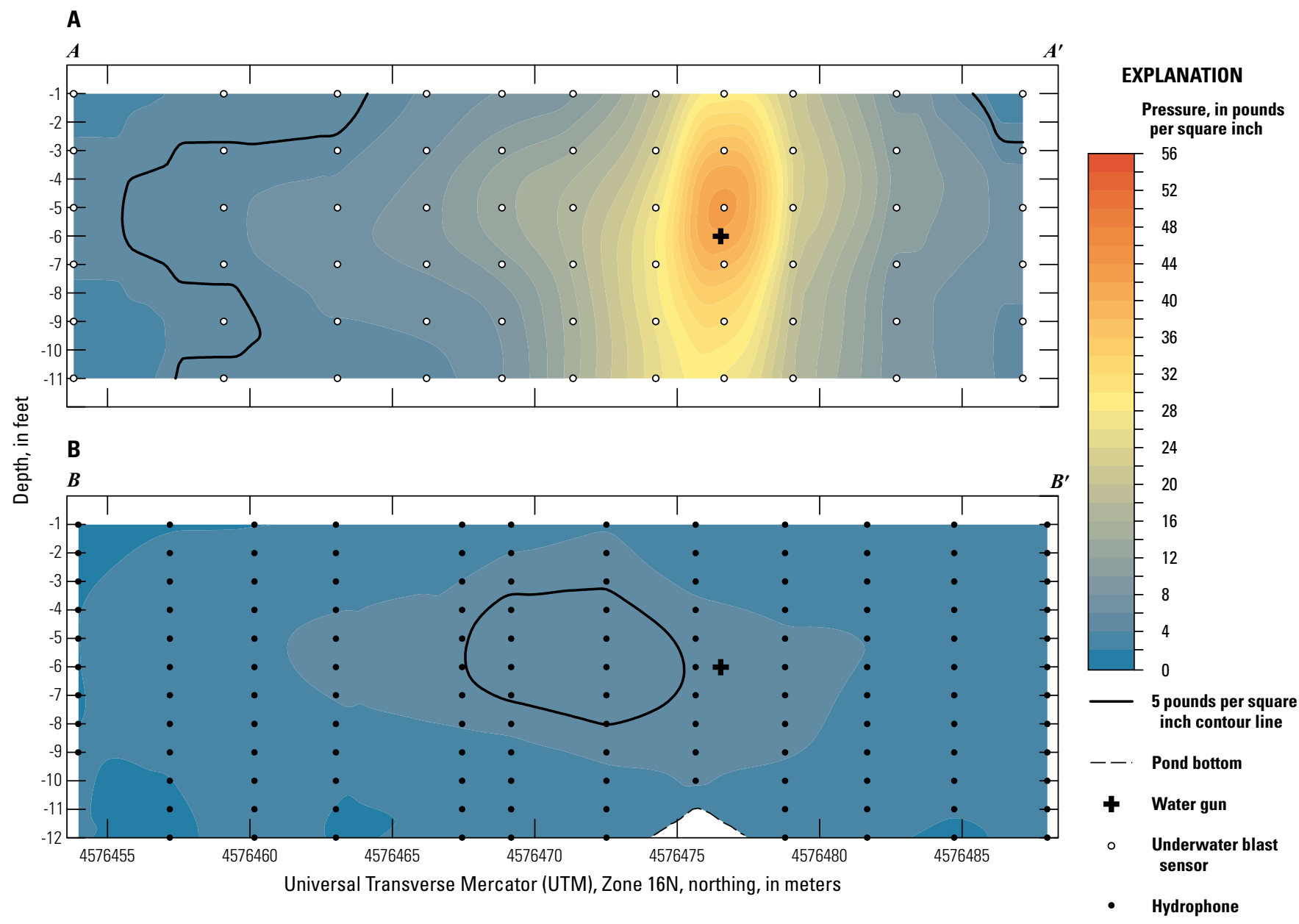

Figure 1-7. Cross-sectional pressure maps from a 100-cubic-inch water gun fired at 2,000 pounds per square inch, for measurements from underwater blast sensor $\left(A-A^{\prime}, A\right)$ and hydrophone $\left(B-B^{\prime}, B\right)$ profile lines. Water gun marked was the one fired. See figure 14 of main text for locations of cross sections. 


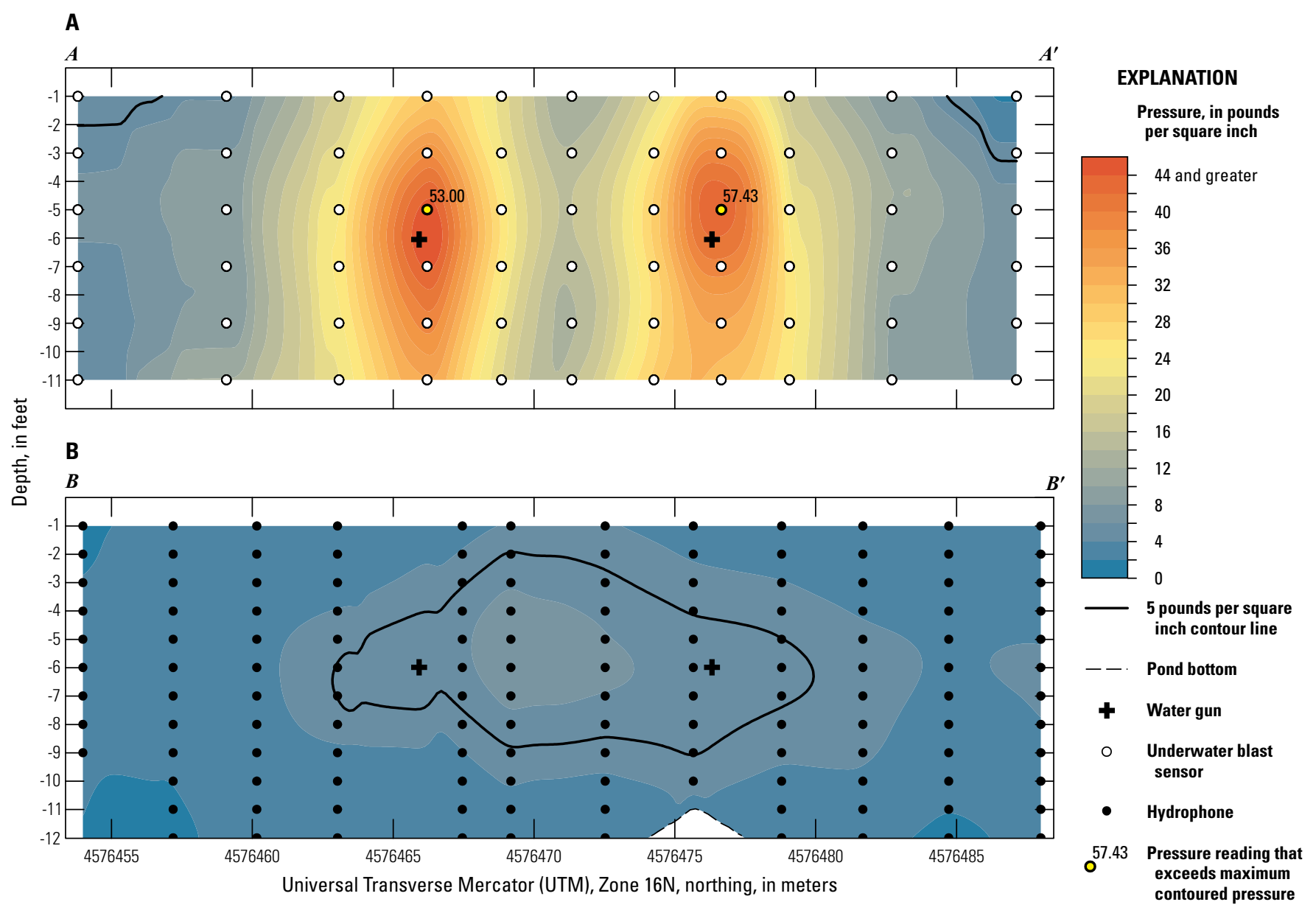

Figure 1-8. Cross-sectional pressure maps from two 100-cubic-inch water guns fired at 2,000 pounds per square inch, for measurements from underwater blast sensor $\left(A-A^{\prime}, A\right)$ and hydrophone $\left(B-B^{\prime}, B\right)$ profile lines closest to the water guns. See figure 14 of main text for locations of cross sections. 


\section{Appendix 2. Underwater Pressure Data and Data-collection Equipment}

\section{Pressure Data}

Seismic pressure data in this report are formatted as Microsoft Excel files and are available online at http://dx.doi. org/10.3133/sir20165098. All files are arranged by year and sensor in the sir20165098_Morris_Seismic_Data zip folder. Consult the metadata file (.xml) for complete descriptions of column data.

\section{Equipment}

Data were collected by using Instantel Blastware seismographs and a National Instruments data acquisition system linked to a personal computer. Two types of sensors were deployed: OYO Geospace Hydrophones with a sensitivity of $0.0237 \mathrm{lb} / \mathrm{in}^{2}$ and PCB Piezotronics Underwater Blast Sensors with a sensitivity of $0.02 \mathrm{lb} / \mathrm{in}^{2}$. 


\section{Appendix 3. Ground Velocity Data and Data-collection Equipment}

\section{Ground Velocity Data}

Seismic ground velocity data in this report are online in the SEG-2 format at http://dx.doi.org/10.3133/sir20165098. Seismic data can be accessed through standard geophysical software that is capable of reading SEG-2 files. Software capable of reading SEG-2 format is available and documented in U.S. Geological Survey Open-File Report 03-141 (Ellefsen, 2003), available at http://pubs.usgs.gov/of/2003/ofr-03-141/. Other open-source software, such as Geopsy (available at http://www.geopsy.org/), is available to read SEG-2 formatted data. These files are arranged in the sir20165098_Morris Seismic_Data zip folder.

\section{Equipent}

Data were collected by using Geometrics Geode seismographs and on personal computers with Single Geode Operating System (SGOS) and Multiple Geode Operating System (MGOS) software.

One type of three-component (3C) sensors was deployed: RTClark 10-hertz $(\mathrm{Hz})$ surface geophones. Each of the three components corresponds to channels as shown below:

\section{0-Hz surface geophones}

- Channel 1: transverse component

- Channel 2: longitudinal component

- Channel 3: vertical component

\section{Morris Sand and Gravel Pond Sensor Configurations and Shot Information (80-cubic-inch water gun)-August 12, 2014}

Files 81201.dat through 81276.dat

[ft, feet; $1 \mathrm{~b} / \mathrm{in}^{2}$, pounds per square inch; $3 \mathrm{C}$, three-component]

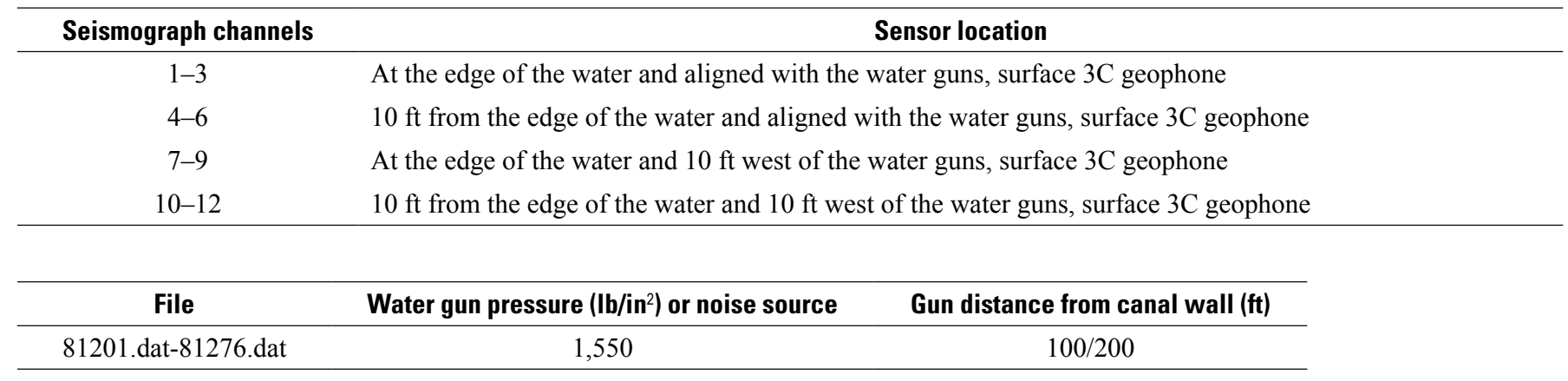


Morris Sand and Gravel Pond Sensor Configurations and Shot Information (80-cubic-inch water gun)-August 13, 2014

Files 81277.dat through 81310.dat

[ft, feet; lb/in ${ }^{2}$, pounds per square inch]

\begin{tabular}{ccc}
\hline File & Water gun pressure $\left(\mathbf{I b} / \mathbf{i n}^{2}\right)$ or noise source & Gun distance from canal wall (ft) \\
\hline 81277.dat-81310.dat & 1,550 & $100 / 200$ \\
\hline
\end{tabular}

Morris Sand and Gravel Pond Sensor Configurations and Shot Information (80-cubic-inch water gun)—August 14, 2014

Files 81311.dat through 81356.dat

[ft, feet; lb/in ${ }^{2}$, pounds per square inch]

\begin{tabular}{ccc}
\hline File & Water gun pressure $\left(\mathbf{I b} / \mathbf{i n}^{2}\right)$ or noise source & Gun distance from canal wall (ft) \\
\hline 81311.dat-81356.dat & 1,550 & $100 / 200$ \\
\hline
\end{tabular}



Menlo Park Publishing Service Center, California Manuscript approval date June 27, 2016

Edited by Regan Austin

Design and layout by Cory Hurd 


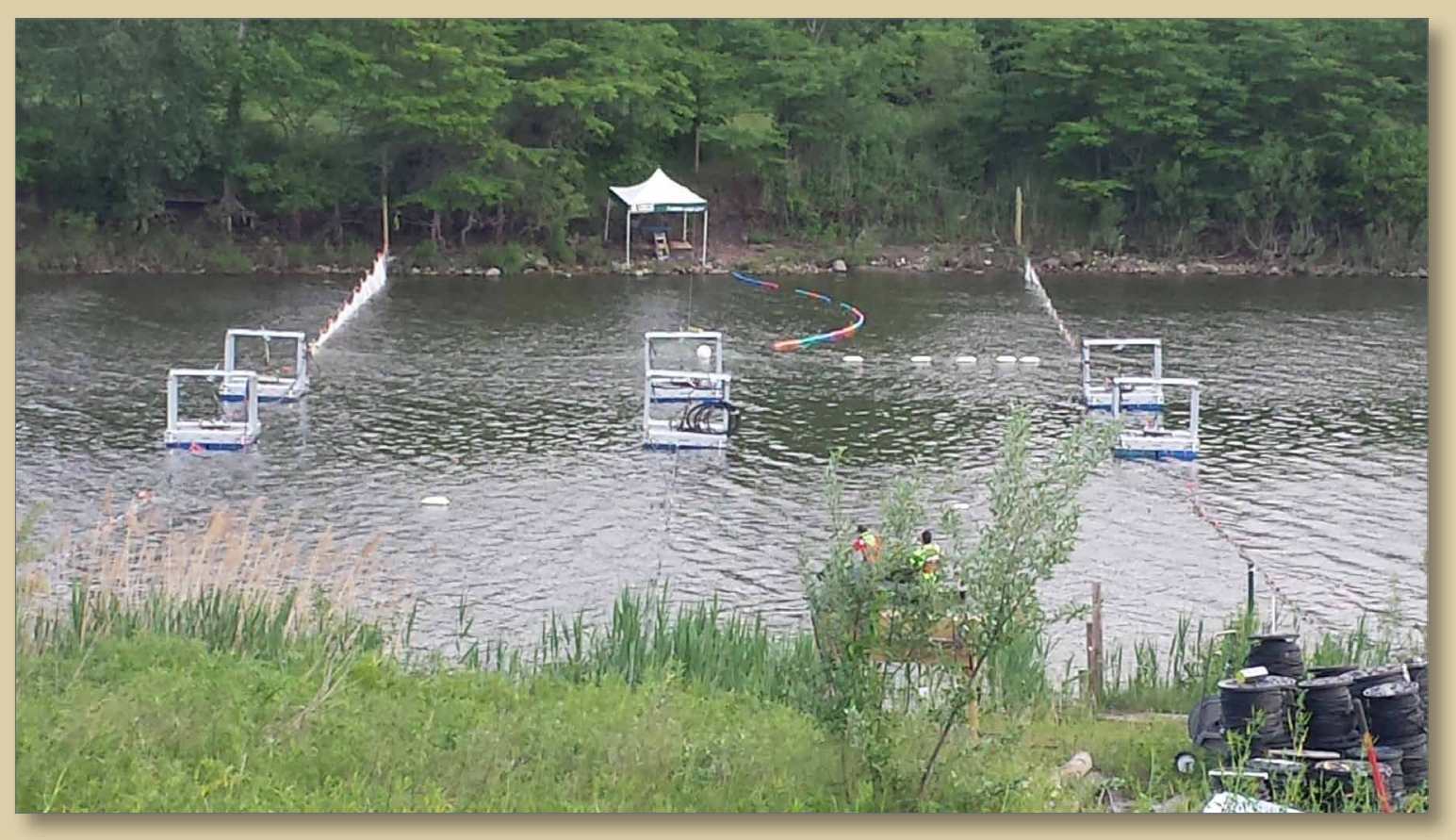

